\title{
THE OPTIMIZATION OF THE SHAPE AND SIZE OF THE INJECTION CONTACTS OF THE INTEGRATED P-I-N-STRUCTURES ON THE BASE OF USING THE CONFORMAL MAPPING METHOD
}

\author{
Bomba A. Ya. - Dr. Sc., Professor, Department of Computer Science and Applied Mathematics, National Univer-
} sity of Water and Environmental Engineering, Rivne, Ukraine.

Moroz I. P. - PhD, Associate Professor, Department of Informatics and Applied Mathematics, Rivne State University of Humanity, Rivne, Ukraine.

Boichura M. V. - Junior Researcher, Scientific and Research Department, National University of Water and Environmental Engineering, Rivne, Ukraine.

\begin{abstract}
Context. P-i-n-diodes are widely used in a microwave technology to control the electromagnetic field. The field is controlled by the formation of an electron-hole plasma in the region of an intrinsic semiconductor (i-region) under the influence of a control current. The development of control devices on p-i-n-diodes has led to the emergence of integral p-i-n-structures of various types, the characteristics of which (for example, switching speed, switched power level, etc.) exceed the similar characteristics of volume diodes. The properties of $\mathrm{p}$-i-n-structures are determined by a number of processes: the diffusion-drift charge transfer process, the recombination-generation, thermal, injection, and the so on. Obviously, these processes should be taken into account (are displayed) in the mathematical model of the computer-aided design system for control devices of a microwave systems. Integrated process accounting leads to the formulation of complex tasks. One of them is the task of optimizing the shape, geometric dimensions and placement of the injected contacts (an active region).

Objective. The goal of the work is the development of a mathematical model and the corresponding software of the process of a microwave waves interaction with electron-hole plasma in an active region of the surface-oriented integral p-i-n-structures with ribbon-type freeform contacts to optimize an active region shape and its geometric dimensions.

Method. The main idea of the developed algorithm is to use the conformal mapping method to bring the physical domain of the problem to canonical form, followed by solving internal boundary value problems in this area for the ambipolar diffusion equation and the wave equation using numerical-analytical methods (the finite difference method; partial domains method using projection boundary conditions similar to the Galerkin method). The optimization algorithm is based on a phased solution of the following problems (the shape and geometric dimensions of the active region are specified at each stage): a computational grid of nodes for the physical regions of the problem is being found, in an active region the carriers concentration distribution is being determined and the energy transmitted coefficient in the system under study is being calculated, which is used in the proposed optimization functional. The extreme values of the functional are found by the uniform search method.

Results. The proposed mathematical model and the corresponding algorithm for optimizing the shape and geometric dimensions of the active region (i-region) of integrated surface-oriented p-i-n-structures expands the tool base for the design of semiconductor circuits of microwave frequencies (for example, similar to CST MICROWAVE STUDIO).

Conclusions. An algorithm has been developed to optimize the shape and geometrical dimensions of the active region of integrated surface-oriented $\mathrm{p}$-i-n-structures with in-depth contacts intended for switching millimeter-wave electromagnetic signals. The universality of the algorithm is ensured by applying the method of conformal transformations of spatial domains. The example of the application of the proposed algorithm to search for the optimal sizes of wedge-shaped (in cross-section) contacts of silicon structures is considered.
\end{abstract}

KEYWORDS: conformal mapping method, parameter optimization, ambipolar diffusion process, wave process, microwave electromagnetic field switches, integrated $\mathrm{p}-\mathrm{i}-\mathrm{n}$ structure.

\begin{abstract}
ABBREVIATIONS
EMW is an electromagnetic wave; EDM is an electrodynamic model; QHM is a quasi-hydrodynamic model; DDM is a diffusion-drift model.
\end{abstract}

\section{NOMENCLATURE}

$b$ is a p-i-n-structure substrate thickness; $d$ is a half period contact placement; $D_{p}, D_{n}$ are the diffusion coefficients of holes and electrons, respectively;

$e$ is an electron's charge;

$\vec{E}$ is an electric field strength vector;

$E^{\text {in }}$ is an electrical component amplitude of the incident electromagnetic wave;
$E_{i}^{\text {out }}$ is an amplitude of the $i$-th wave mode passing through the p-i-n-structure in the electrodynamic tract;

$e_{k}^{(m)}, h_{k}^{(l)}$ are the $k$-th eigenfunctions of the electromagnetic wave equation in a rectangular waveguide;

$h$ is a contact depth;

$\vec{H}$ is a magnetic field strength vector;

$J$ is a density of control current (injection current); $j_{n, p}$ is a hole or an electron current density;

$k$ is a wavenumber;

$L$ is a domains contour;

$L_{A}, L_{B}$ are the rectangular waveguide dimensions;

$m_{n, p}{ }^{*}$ is an effective mass of an electron or a hole;

$n$ is an electron's concentration;

$N_{d}$ is an alloying profile;

$p$ is a hole's concentration; 
$S$ is the surfaces of the domains;

$S_{w}, S_{p}, S_{n}$ are the surfaces of the waveguide, the metal electrodes respectively;

$T$ is an energy transmission coefficient;

$V$ or $G$ are the domains of the solving problems;

$w$ is a distance between $\mathrm{p}-\mathrm{i}-, \mathrm{n}-\mathrm{i}-\mathrm{junctions}$;

$\alpha_{p}, \alpha_{n}$ are the charge recombination coefficients at $p-i-$ or n-i-junction;

$\delta$ is an accuracy;

$\delta p, \delta n$ are the concentrations unbalanced holes and electrons;

$\widetilde{\Delta}$ is a determinant of the Jacobi transformation matrix;

$\varepsilon$ is a dielectric permittivity;

$\varepsilon_{L}$ is a dielectric permittivity of a crystal grid;

$\varepsilon_{0}$ is an electrostatic constant;

$\lambda$ is a wavelength in an unlimited medium;

$\lambda_{c}$ is a conformal invariant;

$\mu_{p}, \mu_{n}$ are the mobilities of a hole and an electron;

$v_{n, p}$ is a collision frequency;

$\tau_{\mathrm{p}}{ }^{*}, \tau_{\mathrm{n}}{ }^{*}$ are the relaxation lifetimes of a hole and an electron;

$\varphi$ is an electrical potential;

$\omega$ is a circular oscillation frequency of an external electromagnetic field.

\section{INTRODUCTION}

A microwave switch is an important element of a radar system. Semiconductor devices on the p-i-n-diodes are widely used for the electromagnetic fields switching $[1,2]$. The switching process comes at the expense of formation in the active regions of diodes (i-region) of the electron-hole plasma (that shields the electromagnetic field). This is due to the injection of charge carriers from the contact $(\mathrm{p}-\mathrm{i}, \mathrm{n}-\mathrm{i})$ regions under a control current $[1,2]$.

The process of improving switches based on the $p-i-n-$ diodes led to the appearance of integrated $p$-i-n-structures (specialized chip). Integrated surface-oriented $\mathrm{p}-\mathrm{i}-\mathrm{n}$ structure is a plate made of silicon or other similar material, where a set of the injecting $n-i$ and $p-i$ junctions is formed on one of the sides [3-5], see Fig. 1a. The arrangement of the structure in a rectangular waveguide (in the YOZ plane) for the electromagnetic field control is shown schematically in Fig. $1 b$.

The basic characteristics of the microwave switch (field attenuation level, switching time, frequency characteristics) are determined by a kind, the geometry of the structure and the injection contacts, the parameters of the electron-hole plasma formed in the i-region (active region) of the p-i-n-structure. The study of switches properties at the design and optimization stage is based on a number of mathematical models. In particular, electrodynamic models (EDM), engineering approaches are used to establish the electrodynamic characteristics of a system; the equations of a quasi-hydrodynamic model (QHM) describe the properties of material media $[1,2,6,7]$. In general formulation, the problem is complex, so different approximations are used. For example, characteristics are averaged; additional conditions are imposed on the proc(C) Bomba A. Ya., Moroz I. P., Boichura M.V., 2021 DOI 10.15588/1607-3274-2021-1-2 esses of formation of an electron-hole plasma (for example, the influence of thermal effects is considered to be insignificant), on the course of the wave process in the system; the model ideas about the physical subdomains of the system are used, etc. Such simplifications provide the problem solving algorithm's performance, permit a general understanding about the behavior of the microwave switches on the p-i-n-structures, but simplified mathematical models do not allow to obtain adequate optimization algorithms.

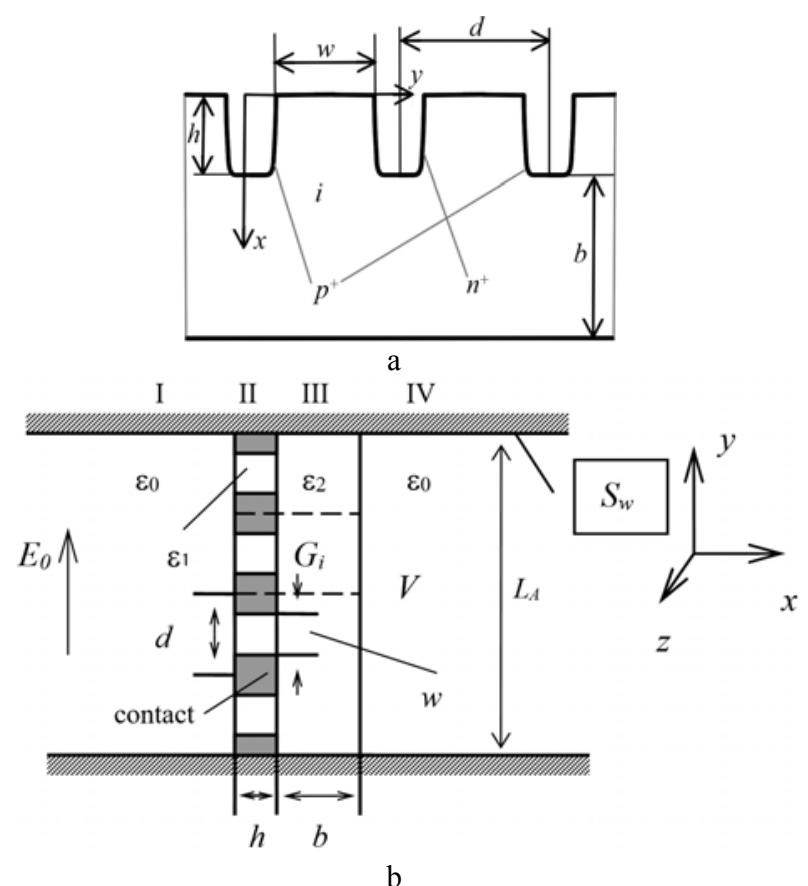

Figure 1 - Schematic representations of the p-i-n-structure (a) and the microwave switch (b)

The object of study is the processes in the semiconductor microwave control devices.

The subject of study is the methods and the tools for mathematical modeling of the physical processes in the switching devices on integral surface-oriented $\mathrm{p}-\mathrm{i}-\mathrm{n}$ structures with an active region of an arbitrary configuration.

The aim of the work is the development of the mathematical model of the process of interaction of microwave waves with the electron-hole plasma of the active region of switching semiconductor surface-oriented integral $\mathrm{p}-\mathrm{i}$ n-structures, which taking into account, based on the use of complex analysis methods, the arbitrariness of the choice of the shape and geometric dimensions of the active region, and the procedure for selecting the parameters of the active region for ensuring optimal switching characteristics of the respective systems.

\section{PROBLEM STATEMENT}

Let the active region of the integrated surface-oriented p-i-n-structure be a chain of similar elements (region $G_{i}$, Fig. 1). The structure element is shown schematically in Fig. 2. Under the action of the control current electrons 
and holes penetrate into the active region of the structure through the injecting $\mathrm{n}-\mathrm{i}$ and $\mathrm{p}-\mathrm{i}$ contacts respectively (circuit elements $L_{n}$ and $L$ p, Fig. 2) and significantly change the electrodynamic characteristics of the active region. The $\mathrm{p}-\mathrm{i}-\mathrm{n}$-structure is installed in a rectangular metal waveguide of the millimeter wavelength range. The waveguide is disturbed by the main $T E_{10}$ mode with specified characteristics (amplitude, frequency, phase).

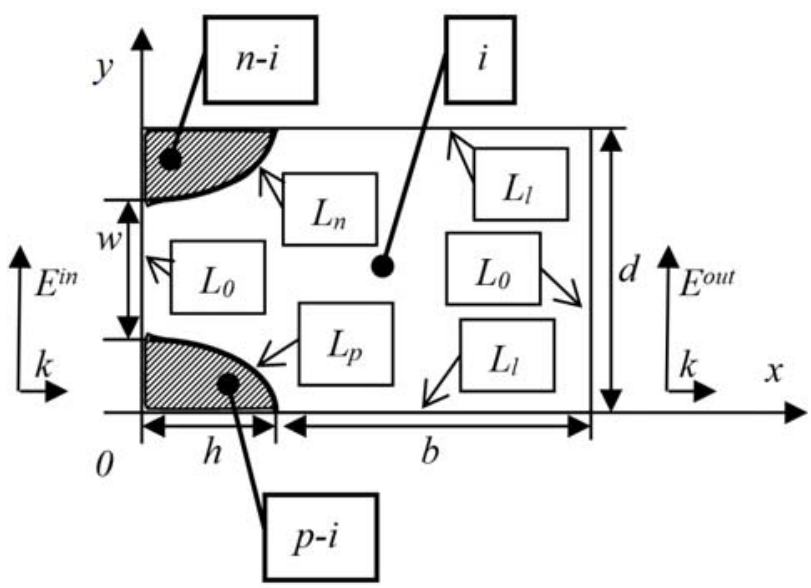

Figure 2-2D model of element of integrated p-i-nstructure ( $G$ domain, see Fig. 1b)

To assess the switching properties of an electrodynamic system, it is necessary to find the energy transmit coefficient in the switch:

$$
T(J)=\sum_{i}\left|E_{i}^{\text {out }}(J)\right|^{2} /\left|E^{i n}\right|^{2}
$$

at the presence and absence of a control current. Unknowns $E_{i}^{\text {out }}(J)$ are determined by solving an internal electrodynamic boundary value problem for an infinite rectangular metal waveguide with an inclusion (similar to [8-10]). The electrodynamic characteristics of the active region of the $\mathrm{p}$-i-n-structure are described within the framework of the application of the QHM of the flow of the electron-hole current in semiconductors (similarly to $[1,2,6-7])$. The electrodes system is assumed to be ideally conducting.

One of the features of the problem is that the domain $G$, in general case, non-canonical. It contains curvilinear sections of its boundary $\left(L_{p}, y=g_{p}(x, w, h) ; \quad L_{n}\right.$, $y=g_{n}(x, w, h)-$ the sections of injection contacts $)$. And this makes it impossible to directly apply previously developed methods (for example [4,5]) for calculating the system electrodynamic characteristics. In this case, an important subproblem is to reduce the original problem in the curvilinear domain to the corresponding problem in the canonical domain using the developed special numerical procedure for conformal mappings. In addition, a condition is set for the development of an algorithm for finding the geometric dimensions $(d-\widetilde{w}, \widetilde{h})$ of contacts for a given shape to ensure, in a certain sense, the optimal characteristics of the corresponding technical system in order to increase the efficiency of its operation.

Below is the corresponding mathematical formulation of the problem described above.

\section{REVIEW OF THE LITERATURE}

The considered switches of the microwave field based on the integrated p-i-n-structures are a new type of the electrodynamic systems. The operation of the switches based on the integrated p-i-n-structures is based on the same physical principles as the operation of the traditional microwave switches on the bulk p-i-n-diodes. Accordingly, the similar mathematical models are used to formally describe these devices. However, these types of switches differ significantly in design and, accordingly, switches based on the integrated $p$-i-n-structures have characteristics that differ from the traditional switching systems. Let's briefly review the basic mathematical models.

Physical phenomena occurring in p-i-n-diodes in stationary, non-stationary and transient modes of operation can be studied in detail on the basis of a number of theoretical models. The diffusion-drift model (DDM) has become classic. The scope of the model is limited by the spatial characteristics of processes exceeding the relaxation lengths of the momentum and the energy of the charge carriers. For a sufficiently wide class of radioelectronics devices, this model provides good results. Such mathematical models are based on continuity equations $[6,7]$ :

$$
\begin{aligned}
& \frac{\partial p}{\partial t}=-\frac{1}{e} \operatorname{div\vec {j}_{p}}-\frac{\delta p}{\tau_{p}{ }^{*}}, \\
& \frac{\partial n}{\partial t}=\frac{1}{e} \operatorname{div}_{n}-\frac{\delta n}{\tau_{n}{ }^{*}}
\end{aligned}
$$

the hole and electron current density equations:

$$
\begin{aligned}
& \vec{j}_{p}=e \mu_{p} p \vec{E}-e D_{p} \text { gradp }, \\
& \vec{j}_{n}=e \mu_{n} n \vec{E}+e D_{n} \text { gradn } ;
\end{aligned}
$$

and Maxwell's third equation:

$$
\operatorname{div}\left(\varepsilon_{0} \varepsilon \vec{E}\right)=e\left(p-n+N_{d}\right),(\vec{E}=-\operatorname{grad} \varphi) .
$$

In the general case, the mobility and diffusion coefficients of electrons and holes are functions of the temperature and of the electric field strength $\mu_{n}=\mu_{n}(T, E)$, $\mu_{p}=\mu_{p}(T, E), D_{n}=D_{n}(T, E), D_{p}=D_{p}(T, E)$. The relaxation times $\tau_{\mathrm{p}}{ }^{*}, \tau_{\mathrm{n}}{ }^{*}$ are also functions of temperature, concentration of holes, electrons and recombination centers. The kind of these functions depends on the recombination mechanism. In many practical cases only the ShockleyRead recombination is considered. 
Since the p-contact (contour $L_{p}$, see Fig. 2) provides injection into the active region of holes only, and the ncontact (contour $L_{n}$ ) of electrons only, the system of equations (1-3) is supplemented by the boundary conditions in the form:

$$
\begin{gathered}
e \mu_{p} p E_{v}-e D_{p} \frac{\partial p}{\partial v}-\left.e \alpha_{p} p\right|_{L_{p}}=J_{v}, \\
e \mu_{n} n E_{v}+e D_{n} \frac{\partial n}{\partial v}-\left.e \alpha_{n} n\right|_{L_{p}}=0, \\
e \mu_{p} p E_{v}-e D_{p} \frac{\partial p}{\partial v}-\left.e \alpha_{p} p\right|_{L_{n}}=0, \\
e \mu_{n} n E_{v}+e D_{n} \frac{\partial n}{\partial v}-\left.e \alpha_{n} n\right|_{L_{n}}=J_{v}, \\
e \mu_{p} p E_{v}-e D_{p} \frac{\partial p}{\partial v}-\left.e \alpha_{p} p\right|_{L_{0}}=0, \\
e \mu_{n} n E_{v}+e D_{n} \frac{\partial n}{\partial v}-\left.e \alpha_{n} n\right|_{L_{0}}=0 .
\end{gathered}
$$

The recombination coefficients $\left(\alpha_{\mathrm{p}}, \alpha_{\mathrm{n}}\right)$ are introduced in a phenomenological way. $J_{v}=J$ is the injection current. $L_{0}$ is a contour of the surface of the integrated $\mathrm{p}$-i-nstructure; $\vec{v}$ is a normal vector to the $L\left(L=L_{p} \cup L_{n} \cup L_{0} \cup L_{l}\right)$ contour, which bounds a domain $G$.

The boundary conditions for the potential have the form:

$$
\left.\varphi\right|_{L_{p}}=U,\left.\varphi\right|_{L_{n}}=0 .
$$

where $U$ is a potential difference (voltage) between the p-i-n-structure contacts.

Depending on the specific form of the boundary conditions for solving the system of equations (2-4), the corresponding analytical methods (for example, the method of separation of variables), combined analytical-numerical methods (for example, the method of partial domains), or numerical methods (for example, difference methods) are used.

The results of solving of the system of equations (1-3) with the boundary conditions (4-8) provide the opportunity to obtain the complex function that determines the dielectric permittivity $\varepsilon(x, y)$ (response to the action of an external field) of the active region of p-i-n-structures [7]:

$$
\varepsilon(x, y, J)=\varepsilon_{L}-\frac{e^{2}}{\varepsilon_{0} \omega}\left(\frac{n(x, y, J)}{m_{n}^{*}\left(\omega-i v_{n}\right)}-\frac{p(x, y, J)}{m_{p}^{*}\left(\omega-i \nu_{p}\right)}\right) .
$$

The switch energy transmission coefficient (1) in the electrodynamic tract is found by solving the system of Maxwell's equations [8-10], which is written with respect to complex amplitudes, in each of the selected subdomains I, II, III, IV (Fig. 1b) (EDM):

$$
\left\{\begin{array}{l}
\operatorname{rot} \vec{H}_{m}=i \omega \hat{\varepsilon} \vec{E}_{m}, \\
\operatorname{rot} \vec{E}_{m}=-i \omega \hat{\mu} \vec{H}_{m},
\end{array}\right.
$$

where $\vec{E}_{m}=\vec{E}_{m}(x, y, z), \vec{H}_{m}=\vec{H}_{m}(x, y, z)$ are vector functions that determine the strengths of electric and magnetic fields in the subdomains $(m=1 \ldots 4)$ of the electrodynamic $\wedge \wedge$

system $V$ (Fig. 1b); $\varepsilon, \mu$ are the dielectric and magnetic permeability tensors of the medium, respectively. We note that in this problem, each subregion is isotropic, inhomogeneous, and nonmagnetic. It is reflected by a specific kind of tensors. The system of equations (11) is supplemented by the boundary conditions at the surface $S_{w}$ of the waveguide and at the surfaces of the integrated structure metal electrodes $S_{p}, S_{n}$ :

$$
\begin{gathered}
{\left.[\overrightarrow{\mathrm{v}}, \vec{E}]\right|_{S_{w}, S_{p}, S_{n}}=0,} \\
{\left.\left[\overrightarrow{\mathrm{v}}, \frac{\partial \vec{H}}{\partial \zeta}\right]\right|_{S_{w}, S_{p}, S_{n}}=0,}
\end{gathered}
$$

where $\vec{v}$ is normal to surfaces $S_{w}, S_{p}, S_{n} ; \zeta$ is a local coordinate along the normal to the surfaces. Relations (11) take into account the ideal conductivity of the electric current by the walls of a waveguide. They determine the type of waves (modes) existing in the investigated regions.

The "bonding" of the problem (10-11) solutions in the partial regions is carried out by the projection boundary conditions of the form [8-10]:

$$
\begin{aligned}
& \left.\int_{S_{\perp}} \mid E^{(m)}-E^{(l)}, h_{k}^{(l)}\right] d s=0, \\
& \int_{S_{\perp}}\left[e_{k}^{(m)}, H^{(m)}-H^{(l)}\right] d s=0,
\end{aligned}
$$

where $S_{\perp}$ is a cross-section surface of a rectangular waveguide (domain $V$ ).

The boundary conditions (12) are written in the form of a projection analog of the continuity condition of tangential constituents $E_{\tau}$ and $H_{\tau}$ at the junction of subregions. They are equivalent to the statement: the eigenfunctions of the subregion $V_{m}$ are decomposed by the eigenfunctions of the subregion $V_{l}$ and vice versa.

The waveguide is perturbed by the rectangular waveguide main mode $T E_{10}$ (the process parameters such as 
amplitude, oscillation frequency, phase, are given), which propagates in the $x$-axis direction.

In addition, the solutions of the system (10) must satisfy the perturbation and radiation partial conditions:

$$
\begin{gathered}
\left(\begin{array}{c}
E \\
H
\end{array}\right)_{x \leq 0}=\sum_{n}\left[A_{n}^{+}(x)\left(\begin{array}{c}
E_{n}^{(1)}(y, z) \\
H_{n}^{(1)}(y, z)
\end{array}\right)+B_{n}^{-}(x)\left(\begin{array}{l}
E_{n}^{(1)}(y, z) \\
H_{n}^{(1)}(y, z)
\end{array}\right)\right], \\
\left(\begin{array}{l}
E \\
H
\end{array}\right)_{x \geq h+b}=\sum_{n}\left[C_{n}^{+}(x)\left(\begin{array}{l}
E_{n}^{(2)}(y, z) \\
H_{n}^{(2)}(y, z)
\end{array}\right)\right]
\end{gathered}
$$

where $A_{n}^{+}(x), C_{n}^{+}(x), B_{n}^{-}(x)$ are functions that describe the waves generated in the system, propagate along the $x$ axis and in the opposite direction respectively.

Obviously, in order to obtain the basic characteristics of microwave switches, the system of equations (10) (electrodynamic problem) and (2-4) (diffusion-drift problem) with the corresponding boundary conditions must be solved sequentially. Depending on the structure of the commuting system the boundary conditions are specified and simplifying assumptions are selected.

The problem of estimating the value of the energy transfer coefficient of a switch on an integrated surfaceoriented $\mathrm{p}$-i-n-structure with strip contacts is complicated by the fact that the $\mathrm{i}$-region of the structure in general case non-canonical. The presence of a periodic lattice of electrodes on the surface of the $\mathrm{p}$-i-n-structure further complicates the formulation and solution of the electrodynamic problem. Known from literary sources (for example, [11]) computational schemes in such cases use a specific record of the boundary conditions, which are presented in a complex form.

A feature of this study is the use of conformal mapping $[12,13]$ reduce non-canonical regions of the electrodynamic system to the canonical form. This approach takes into account the structural features of the switch in the integrated form and provides an opportunity to obtain a more universal algorithm for calculating the characteristics of the corresponding technical systems.

\section{MATERIALS AND METHODS}

Using decomposition approach the set task is reduced to a number of "subtasks": 1) the problem of conformal mappings and the reduction of the original problem to the canonical domain; 2) to find the solution of the classical diffusion problem in the canonical domain; 3 ) to find the solution of classical electrodynamic problems in the conditions of "gluing" their solutions; 4) construction of a decision-making algorithm for optimizing parameters (the width of the base (d-w) and the depression (h) of the electrode are selected for a given shape).

1) One way to solve the problem of transforming physical domains to canonical form is to use the conformal mapping method [12-14] (the corresponding algorithm is numerically implemented on a computer, which ensures its universality).
Due to the symmetry of the $G$ domain (Fig. 3a) we map its upper subdomain $G^{\prime}$ with the boundary $\partial G^{\prime}=A B C D E$ to the interior of the rectangle $\widetilde{G}^{\prime}=\left\{(\tilde{x}, \tilde{y}): \widetilde{x}_{*}<\tilde{x}<\widetilde{x}^{*}, 0<\tilde{y}<Q\right\} \quad$ with border $\partial \widetilde{G}^{\prime}=\widetilde{A} \widetilde{B} \widetilde{C} \widetilde{D} \widetilde{E} \quad(\widetilde{z}=\widetilde{x}+\tilde{y}) \quad$ (Fig. 3b) under unknown (sought-for) functions $\tilde{x}=\tilde{x}(x, y), \quad \tilde{y}=\tilde{y}(x, y)$ and parameters $Q, \widetilde{E}$.

The corresponding problem is to solve the CauchyRiemann system

$$
\frac{\partial \widetilde{x}}{\partial x}=\frac{\partial \widetilde{y}}{\partial y}, \frac{\partial \widetilde{x}}{\partial y}=-\frac{\partial \widetilde{y}}{\partial x}
$$

under the boundary conditions:

$$
\begin{gathered}
\left.\tilde{x}\right|_{A B}=\left.\tilde{x}\right|_{y=0,0<x<h+b}=\tilde{x}_{*}, \\
\left.\tilde{x}\right|_{C D}=\left.\tilde{x}\right|_{0<x<h, y=g_{n}(x, w, h)}=\tilde{x}^{*}, \\
\left.\tilde{y}\right|_{A E D}=\left.\tilde{y}\right|_{(x=h+b, 0<y<d) \cup(y=d, h<x<h+b)}=0, \\
\left.\tilde{y}\right|_{B C}=\left.\tilde{y}\right|_{x=0,0<y<0.5 w}=Q ; \\
\int_{M N}-\frac{\partial \tilde{x}}{\partial y} d x+\frac{\partial \tilde{x}}{\partial x} d y=Q, \quad M \in B C, \quad N \in A E D .
\end{gathered}
$$

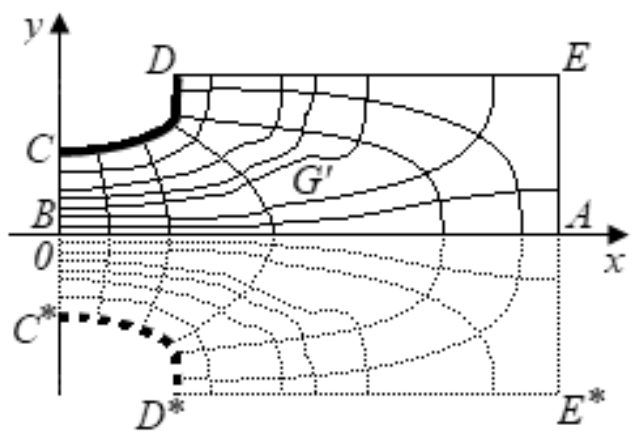

a

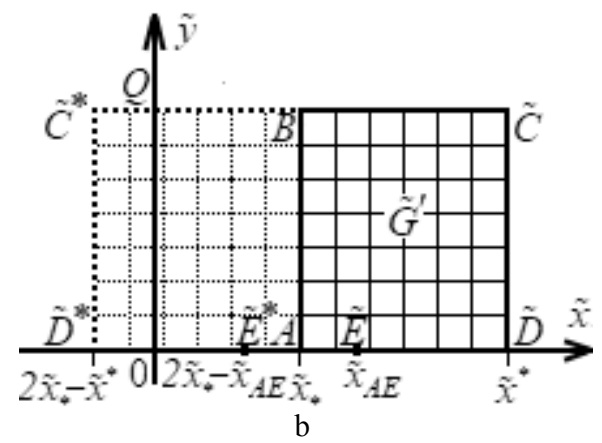

Figure 3 - Physical domain $G^{\prime}$ (a) and corresponding parametric domain $\widetilde{G}^{\prime}(\mathrm{b})$

As it is known [13], it is advisable to carry out inverse conformal mappings $\widetilde{G}^{\prime} \rightarrow G^{\prime}$ when the points $\widetilde{A}, \widetilde{B}$, 
$\widetilde{C}, \widetilde{D}$ correspond to the points $A, B, C, D$. Then the problem is reduced to finding in $\widetilde{G}^{\prime}$ the solutions $x=x(\widetilde{x}, \tilde{y}), y=y(\widetilde{x}, \tilde{y})$ of the Laplace equations

$$
\left\{\begin{array}{l}
\frac{\partial^{2} x}{\partial \widetilde{x}^{2}}+\frac{\partial^{2} x}{\partial \widetilde{y}^{2}}=0, \\
\frac{\partial^{2} y}{\partial \widetilde{x}^{2}}+\frac{\partial^{2} y}{\partial \widetilde{y}^{2}}=0, \forall(x, y) \in G^{\prime}
\end{array}\right.
$$

under the following boundary conditions

$$
\begin{aligned}
& 0 \leq x\left(\tilde{x}_{*}, \tilde{y}\right) \leq h+b, \quad y\left(\tilde{x}_{*}, \tilde{y}\right)=0, \quad 0 \leq \tilde{y} \leq Q, \\
& x(\widetilde{x}, 0)=h+b, \quad 0 \leq y(\widetilde{x}, 0) \leq 0.5 d, \quad \tilde{x}_{*} \leq \tilde{x} \leq \tilde{x}_{A E}, \\
& h \leq x(\widetilde{x}, 0) \leq h+b, y(\widetilde{x}, 0)=0.5 d, \quad \tilde{x}_{A E} \leq \widetilde{x} \leq \widetilde{x}^{*}, \\
& 0 \leq x\left(\widetilde{x}^{*}, \tilde{y}\right) \leq h, \quad y\left(\tilde{x}^{*}, \tilde{y}\right)=g_{n}\left(x\left(\tilde{x}^{*}, \tilde{y}\right), w, h\right), \\
& 0 \leq \tilde{y} \leq Q \text {, } \\
& x(\widetilde{x}, Q)=0, \quad 0 \leq y(\widetilde{x}, Q) \leq 0.5 w, \quad \tilde{x}_{*} \leq \widetilde{x} \leq \widetilde{x}^{*}
\end{aligned}
$$

and the orthogonality conditions (which are simultaneously "connectedness" conditions) [13]:

$$
\begin{gathered}
\frac{\partial x\left(\tilde{x}_{*}, \tilde{y}\right)}{\partial \tilde{x}}=0, \quad 0 \leq \tilde{y} \leq Q, \\
\frac{\partial y(\widetilde{x}, 0)}{\partial \widetilde{y}}=0, \quad \tilde{x}_{*} \leq \tilde{x} \leq \tilde{x}_{A E}, \\
\frac{\partial x(\tilde{x}, 0)}{\partial \tilde{y}}=0, \quad \tilde{x}_{A E} \leq \tilde{x} \leq \tilde{x}^{*}, \\
\frac{\partial x\left(\widetilde{x}^{*}, \tilde{y}\right)}{\partial \widetilde{x}}+\frac{\partial g_{n}\left(x\left(\tilde{x}^{*}, \tilde{y}\right), w, h\right)}{\partial x} \frac{\partial y(\widetilde{x}, \tilde{y})}{\partial \widetilde{x}}=0, \quad 0 \leq \tilde{y} \leq Q, \\
\frac{\partial y(\tilde{x}, Q)}{\partial \widetilde{y}}=0, \quad \tilde{x}_{*} \leq \tilde{x} \leq \tilde{x}^{*} .
\end{gathered}
$$

The problem (16-18) is written in the form of a difference analogue [11,13], using the first-order (left and right) difference schemes and the second-order central difference scheme in the form of:

$$
\begin{gathered}
\left\{\begin{array}{c}
x_{i, j}=\left(x_{i+1, j}+x_{i-1, j}+\lambda_{c}^{2}\left(x_{i, j-1}+x_{i, j+1}\right)\right) /\left(2\left(1+\lambda_{c}^{2}\right)\right), \\
y_{i, j}=\left(y_{i+1, j}+y_{i-1, j}+\lambda_{c}^{2}\left(y_{i, j-1}+y_{i, j+1}\right)\right) /\left(2\left(1+\lambda_{c}^{2}\right)\right) \\
(1 \leq i \leq m, 1 \leq j \leq l) ;
\end{array}\right. \\
0 \leq x_{0, j} \leq h+b, \quad y_{0, j}=0, \quad j=\overline{0, l+1}, \\
x_{i, 0}=h+b, \quad 0 \leq y_{i, 0} \leq 0.5 d, \quad i=\overline{0, m_{A E}}, \\
h \leq x_{i, 0} \leq h+b, \quad y_{i, 0}=0.5 d, \quad i=\overline{m_{A E}+1, m+1}, \\
0 \leq x_{m+1, j} \leq h, \quad y_{m+1, j}=g_{n}\left(x_{m+1, j}, w, h\right), \quad j=\overline{0, l+1}, \\
x_{i, l+1}=0, \quad 0 \leq y_{i, l+1} \leq 0.5 w, \quad i=\overline{0, m+1} ;
\end{gathered}
$$

$$
\begin{gathered}
x_{m+1, j}-x_{m, j}+\frac{\partial g_{n}\left(x_{m+1, j}, w, h\right)}{\partial x}\left(y_{m+1, j}-y_{m, j}\right)=0, \\
j=\overline{1, l}, \quad, \bar{l}, \\
y_{i, l+1}=y_{i, l}, \quad i=\overline{1, m},
\end{gathered}
$$

where $m_{A E}$ is number of nodes in the $A E$ section (is determined in the process of solving the difference problem), $x_{i, j}=x\left(\tilde{x}_{i}, \tilde{y}_{j}\right), y_{i, j}=y\left(\tilde{x}_{i}, \tilde{y}_{j}\right), \quad\left(x_{i, j}, y_{i, j}\right) \in G^{\prime \lambda}$, conformal invariant $\lambda_{\mathrm{c}}$ for domain $\widetilde{G}^{\prime \lambda}=\left\{\left(\tilde{x}_{i}, \tilde{y}_{j}\right)\right.$ : $\tilde{x}_{i}=\widetilde{x}_{*}+i \Delta \widetilde{x}, \quad i=\overline{0, m+1} ; \quad \tilde{y}_{j}=j \Delta \widetilde{y}, \quad j=\overline{0, l+1}$; $\left.\Delta \widetilde{x}=\frac{\widetilde{x}^{*}-\tilde{x}_{*}}{m+1}, \quad \Delta \widetilde{y}=\frac{Q}{l+1}, \quad \lambda_{c}=\frac{\Delta \widetilde{x}}{\Delta \widetilde{y}}, \quad m, l \in \mathbf{N}\right\}$ is determined from condition of "conformal similarity in small" of the corresponding quadrilaterals of two domains [12]:

$$
\lambda_{c}=\frac{1}{(m+1)(l+1)} \sum_{i=0}^{m} \sum_{j=0}^{l} \frac{a_{i, j}+a_{i, j+1}}{b_{i, j}+b_{i+1, j}} .
$$

The following notations are used here:

$$
\begin{aligned}
& a_{i, j}=\sqrt{\left(x_{i+1, j}-x_{i, j}\right)^{2}+\left(y_{i+1, j}-y_{i, j}\right)^{2}}, \\
& b_{i, j}=\sqrt{\left(x_{i, j+1}-x_{i, j}\right)^{2}+\left(y_{i, j+1}-y_{i, j}\right)^{2}} .
\end{aligned}
$$

2) The diffusion-drift problem (similarly to [6,7]) is reduced to solving the system of the differential equations (2-4) in domain $G, G=G_{l} \cup G_{2} \cup\left(\partial \bar{G}_{1} \cap \partial \bar{G}_{2}\right), G_{l}=\{(x, y)$ : $\left.0<x<h, g_{p}(x, w, h)<y<g_{n}(x, w, h)\right\}, G_{2}=\{(x, y): h<x<h+b, 0<$ $y<d\}$ with boundary conditions (5-7) on a closed contour $L=L_{C^{*} D^{*}} \cup L_{D^{*} E^{*}} \cup L_{E^{*} E} \cup L_{E D} \cup L_{D C} \cup L_{C C^{*}}$ boundi ng domain $G$ (Fig. 4). The transition from the threedimensional physical region of the problem to the twodimensional $(G)$ is due to the homogeneity of the integral $\mathrm{p}$-i-n-structure along the $\mathrm{OZ}$ direction and the fulfillment of the condition $d<<L_{B}$.

The periodicity property of the integrated p-i-nstructure gives possibility to consider the properties of only the selected element of the structure (Fig. 4). In this case, the conditions at the boundary of the elements $\left(L_{l}\right)$ are defined as follow:

$$
\begin{gathered}
\left.n\right|_{L_{1}-0}=\left.n\right|_{L_{1}+0},\left.\quad \frac{\partial n}{\partial v}\right|_{L_{1}-0}=\left.\frac{\partial n}{\partial v}\right|_{L_{1}+0}, \\
\left.p\right|_{L_{1}-0}=\left.p\right|_{L_{1}+0},\left.\quad \frac{\partial p}{\partial v}\right|_{L_{1}-0}=\left.\frac{\partial p}{\partial v}\right|_{L_{1}+0} .
\end{gathered}
$$




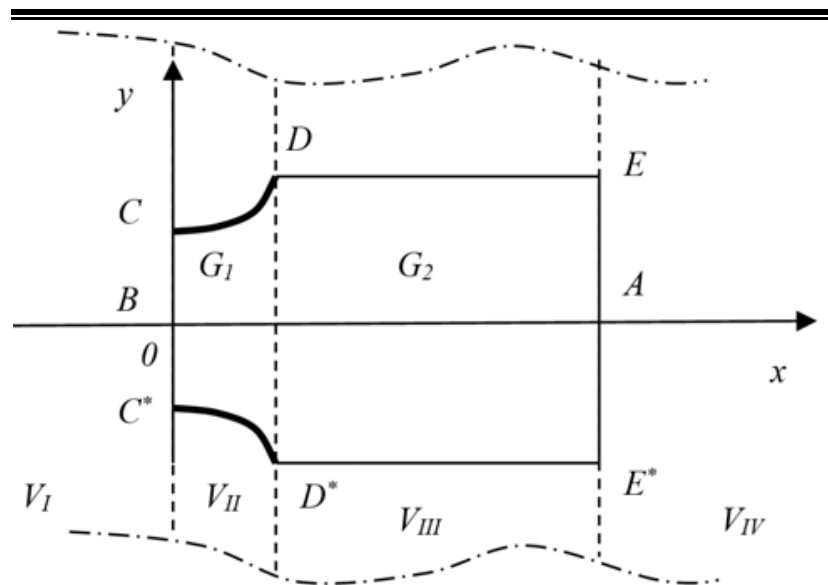

Figure 4 - The physical domain of the problem

We use some additional conditions. 1) The stationary process $(\partial p / \partial t=0, \partial n / \partial t=0)$ is considered. This mode is typical of the microwave switch: the stationary distribution of charge carriers is established in the structure when the control current is supplied to the contacts (the switching time is much higher than the characteristic times of the dynamics of charge carriers in a semiconductor). 2) In general, the system of differential equations (2-4) is nonlinear. This fact significantly complicates the process of problem solving and requires a detailed study of properties of the system and its solutions. However, if we assume that the process of charge carrier propagation takes place in a self-consistent field then the problem is greatly simplified. This mode is often observed in $\mathrm{p}-\mathrm{i}-\mathrm{n}$-structures [4-7]. The terms containing the potential $\varphi$ are removed from the system (2-4) by substitution. We also use the approximation $p \approx n$, which is valid for the larger (central) part of the domain $G$, and the assumption $\tau_{n} \approx \tau_{p}$. As a result, the problem is reduced to solving the ambipolar diffusion equation $[6,7]$ in the form:

$$
\Delta n-\frac{n}{\tau D}=0
$$

where $D=\frac{2 D_{n} D_{p}}{D_{n}+D_{p}}$ is the ambipolar diffusion coefficient, $\Delta=\frac{\partial^{2}}{\partial x^{2}}+\frac{\partial^{2}}{\partial y^{2}}$. The following notation is used: $D \tau=L_{D}^{2}$

Similarly, we obtain the boundary conditions at the boundaries of the domain $G$ (Fig. 4):

$$
\begin{aligned}
& \text { at } L_{C^{*} D^{*}}: \frac{\partial n}{\partial v}-\left.\gamma_{p} n\right|_{L_{p}}=-\frac{J_{v}}{2 e D_{p}} ; \\
& \text { at } L_{C D}: \frac{\partial n}{\partial v}+\left.\gamma_{n} n\right|_{L_{n}}=\frac{J_{v}}{2 e D_{n}} ; \\
& \text { at } L_{C^{*} C} \text { and } L_{E^{*} E}: \frac{\partial n}{\partial v}-\left.\gamma n\right|_{L_{0}}=0 ;
\end{aligned}
$$

$$
\text { at } \begin{array}{r}
L_{D E} \text { and } L_{D^{*} E^{*}}:\left.n\right|_{L_{1}-0}=\left.n\right|_{L_{1}+0}, \\
\left.\frac{\partial n}{\partial v}\right|_{L_{1}-0}=\left.\frac{\partial n}{\partial v}\right|_{L_{1}+0} .
\end{array}
$$

where $\gamma_{n, p}, \gamma$ are charge recombination coefficients on the injection contact regions and surface of structure.

In the canonical domains, the solution of equation (24) with boundary conditions (25) is known. However, as it was shown above, the optimization problem (15) requires taking into account an arbitrary type of elements $L_{C D}$, $L_{C^{*} D^{*}}$ of the boundary of domain $G$ (Fig. 4).

As a result of the change of coordinates $x=x(\tilde{x}, \tilde{y})$, $y=y(\tilde{x}, \tilde{y})$, and the corresponding transformation of the considered region (16-18), the mathematical model of the process of ambipolar diffusion (24-25) of charge carriers in the region $\widetilde{G}$ takes the following form:

$$
\frac{\partial^{2} n}{\partial \widetilde{x}^{2}}+\frac{\partial^{2} n}{\partial \widetilde{y}^{2}}-\frac{n}{L_{D}^{2} \widetilde{\Delta}}=0
$$

where $n(\tilde{x}, \tilde{y})$ is the concentration of charge carriers in the active region of p-i-n-structures, $\widetilde{\Delta}=\left(\frac{\partial \tilde{x}}{\partial x}\right)^{2}+\left(\frac{\partial \tilde{x}}{\partial y}\right)^{2}=\left(\frac{\partial \widetilde{y}}{\partial x}\right)^{2}+\left(\frac{\partial \widetilde{y}}{\partial y}\right)^{2}$ is the determinant of the Jacobi transformation matrix.

Boundary conditions at $\partial \widetilde{G}$ :

$$
\begin{aligned}
& \text { at } L_{C^{*} D^{*}}: \frac{\partial n}{\partial \widetilde{x}}-\left.\gamma_{p} n\right|_{L_{p}}=-\frac{J_{\widetilde{x}}}{2 e D_{p}} \text {; } \\
& \text { at } L_{C D}: \frac{\partial n}{\partial \widetilde{x}}+\left.\gamma_{n} n\right|_{L_{n}}=\frac{J_{\widetilde{x}}}{2 e D_{n}} \text {; } \\
& \text { at } L_{C C^{*}} \text { та } L_{E^{*} E}: \frac{\partial n}{\partial \widetilde{y}}-\left.\gamma n\right|_{L_{0}}=0 \text {; }
\end{aligned}
$$

$$
\text { at } L_{D E} \text { та } L_{D^{*} E^{*}}:\left.n\right|_{L_{1}-0}=\left.n\right|_{L_{1}+0},\left.\quad \frac{\partial n}{\partial \widetilde{y}}\right|_{L_{1}-0}=\left.\frac{\partial n}{\partial \widetilde{y}}\right|_{L_{1}+0} \text {. }
$$

The following difference analogue is used to solve problem (26-27):

$$
\begin{gathered}
n_{i+1, j}-2 n_{i, j}+n_{i-1, j}+\lambda_{c}^{2}\left(n_{i, j+1}-2 n_{i, j}+n_{i, j-1}-\right. \\
\left.-0.25 n_{i, j}\left(\left(x_{i, j+1}-x_{i, j-1}\right)^{2}+\left(y_{i, j+1}-y_{i, j-1}\right)^{2}\right) / L_{D}^{2}\right)=0, \\
i=\overline{-m, m}, j=\overline{1, n}, \\
\frac{n_{-m, j}-n_{-m-1, j}}{\Delta \widetilde{x}}-\gamma_{p} n_{-m-1, j}=-\frac{J_{\widetilde{x}}}{2 e D_{p}}, j=\overline{1, n}, \\
\frac{n_{m+1, j}-n_{m, j}}{\Delta \widetilde{x}}+\gamma_{n} n_{m+1, j}=\frac{J_{\widetilde{x}}}{2 e D_{n}}, j=\overline{1, n},
\end{gathered}
$$




$$
\begin{gathered}
\frac{n_{i, 1}-n_{i, 0}}{\Delta \widetilde{y}}-\gamma n_{i, 0}=0, i=\overline{-m_{A E}, m_{A E}}, \\
\frac{n_{i, n+1}-n_{i, n}}{\Delta \widetilde{y}}-\gamma n_{i, n+1}=0, i=\overline{-m, m}, \\
n_{i+1,0}-2 n_{i, 0}+n_{i-1,0}+\lambda_{c}^{2}\left(2 n_{i, 1}-2 n_{i, 0}-\right. \\
\left.\quad-n_{i, 0}\left(y_{i, 1}-y_{i, 0}\right)^{2} / L_{D}^{2}\right)=0, \\
i=\overline{-m,-m_{A E}-1}, i=\overline{m_{A E}+1, m} .
\end{gathered}
$$

The formed system of linear algebraic equations (28) is solved by stepwise fixing of $n_{i, j}$ values at the boundary and inside the domain. The condition for the completion of such an iterative process is $\sum_{i, j=0}^{m+1, n+1}\left(n_{i, j}^{(r+1)}-n_{i, j}^{(r)}\right)<\delta$ where $r$ is the iteration number.

3) The transmission coefficient of EMW (1) in the rectangular cross-section waveguide, containing the integrated p-i-n-structure (Fig. 1, b), is found by solving an electrodynamic problem (10-13) in the region $V=$ $\left\{(x, y, z):-\infty<x<\infty, 0 \leq y \leq L_{A}, 0 \leq z \leq L_{B}\right\}$. The solution algorithm is based on the partial domain method [8-10]. According to this method, region $V$ is divided into subdomains so that the medium properties are constant within the selected subdomains. There are four main subdomains in this problem: $V_{\mathrm{I}}=\left\{(x, y, z):-\infty<x<0,0 \leq y \leq L_{A}, 0 \leq z \leq L_{B}\right\}$, $V_{\text {II }}=\left\{(x, y, z): 0<x<h, 0 \leq y \leq L_{A}, 0 \leq z \leq L_{B}\right\}, V_{\text {III }}=\{(x, y, z)$ : $\left.h<x<h+b, 0 \leq y \leq L_{A}, 0 \leq z \leq L_{B}\right\}, V_{\mathrm{IV}}=\{(x, y, z): h+b<x<\infty$, $\left.0 \leq y \leq L_{A}, 0 \leq z \leq L_{B}\right\}$, where I-st and IV-th have the same properties.

Let the system be perturbed by the $T E_{10}$-mode (for this type of waves $E_{x}=0$, the electrical components of the field are perpendicular to the propagation direction). The components of the EMW field (complex amplitudes) are known [8-10]:

$$
\begin{gathered}
H_{x}=-i E_{10} \frac{\pi}{\omega \mu_{0} L_{B}} e^{-i\left(\sqrt{\left(\frac{2 \pi}{\lambda}\right)^{2}-\left(\frac{\pi}{L_{B}}\right)^{2}}\right) x} \cos \left(\frac{\pi z}{L_{B}}\right), \\
E_{y}=E_{10} e^{-i\left(\sqrt{\left(\frac{2 \pi}{\lambda}\right)^{2}-\left(\frac{\pi}{L_{B}}\right)^{2}}\right) x} \sin \left(\frac{\pi z}{L_{B}}\right), \\
H_{z}=E_{10} \frac{1}{\omega \mu_{0}}\left(\sqrt{\left(\frac{2 \pi}{\lambda}\right)^{2}-\left(\frac{\pi}{L_{B}}\right)^{2}}\right)^{-i\left(\sqrt{\left(\frac{2 \pi}{\lambda}\right)^{2}-\left(\frac{\pi}{L_{B}}\right)^{2}}\right) x} \times \\
\times \sin \left(\frac{\pi z}{L_{B}}\right) .
\end{gathered}
$$

(C) Bomba A. Ya., Moroz I. P., Boichura M.V., 2021 DOI 10.15588/1607-3274-2021-1-2
As a result of the interaction of EMW with the integrated $\mathrm{p}$-i-n-structure in the waveguide, the system of $T E_{n m}$ modes is perturbed. The components of the electromagnetic field in such modes are determined based on periodicity property of elements of the integrated structure and the Maxwell's system equations (10) under boundary conditions (11). In the region $V_{\mathrm{I}}$ the complex amplitudes of the field components are described by the following relations:

$$
\begin{gathered}
E_{y}=\left(E_{10}^{1+} \exp \left(-i k_{1}^{(1)} x\right)+E_{10}^{1-} \exp \left(i k_{1}^{(1)} x\right)\right) \sin g_{1} z+ \\
+\sum_{m=1}^{\infty} E_{1 m}^{1-} \exp \left(\alpha_{m} x\right) \cos \alpha_{m} y \sin g_{1} z, \\
E_{z}=-\sum_{m=1}^{\infty} E_{1 m}^{1-} \frac{\alpha_{m}}{g_{1}} \exp \left(\alpha_{m} x\right) \sin \alpha_{m} y \cos g_{1} z, \\
H_{z}=\frac{c}{\omega}\left(k_{1}^{(1)}\left(E_{10}^{1+} \exp \left(-i k_{1}^{(1)} x\right)-E_{10}^{1-} \exp \left(i k_{1}^{(1)} x\right)\right) \sin g_{1} z+\right. \\
\left.+\sum_{m=1}^{\infty} i \alpha_{m} E_{1 m}^{1-} \exp \left(\alpha_{m} x\right) \cos \alpha_{m} y \sin g_{1} z\right), \\
H_{y}=i \frac{c}{\omega} \sum_{m=1}^{\infty} E_{1 m}^{1-} \frac{\alpha_{m}}{g_{1}} \alpha_{m} \exp \left(\alpha_{m} x\right) \sin \alpha_{m} y \cos g_{1} z,
\end{gathered}
$$

where $\quad \alpha_{m}=\frac{\pi m}{d} ; \quad g_{l}=\frac{\pi l}{L_{B}} ; \quad k_{l}^{r^{2}}=k_{r}^{2}-g_{l}^{2} ;$ $k_{r}=\frac{2 \pi}{\lambda} \sqrt{\varepsilon_{r} \mu_{r}} ; \lambda=\frac{2 \pi c}{\omega} ; r$ is a sub-domain number; $\varepsilon_{I, I V}=1 ; \varepsilon_{\text {III }}$ is defined by function (9), which is averaged within $V_{\mathrm{III}} ; \mu_{r}=1 ; E_{l m}^{r+}$ are the amplitudes of the modes propagating along the OX direction, $E_{l m}^{r-}$ are the amplitudes of modes propagating in the opposite direction to OX. The structure of the solutions of the problem (10-11) in the regions $V_{\mathrm{III}}, V_{\mathrm{IV}}$ has a similar form.

The corresponding dependencies are also obtained as a result of solving the second boundary value problem for the Helmholtz equation $\left(\Delta_{\perp} H_{z}+k^{2} H_{z}=0\right)$ relative the strength of the field magnetic component vector $H_{z}$ in the domain $\left\{(y, z): 0 \leq y \leq L_{A}, 0 \leq z \leq L_{B}\right\}$ [8-10], which is equivalent to problem (10-11).

The main difficulties are caused by the solution of the problem $(10-11)$ in $V_{\mathrm{II}}$, which is characterized by heterogeneity and anisotropy. This domain consists of the metal sub-regions of the injection contacts and semiconductor cells $\left(G_{1}\right)$ in which the electron-hole plasma is formed. It is known [8-10] that there is no electromagnetic field in metal (under ideal conditions, when the conductivity of the metal tends to infinity). Thus, electromagnetic waves do not penetrate into the volume of metal contacts. Regions $\left(G_{1}\right)$ are similar in shape to horn electrodynamic systems (a kind of irregular waveguide). It is also known $[15,16]$ that the search for solutions of the problem $(10$ 13) in the irregular waveguides is a complex problem. One way for solving the problem is to convert the physical domain $G_{1}$ to the canonical form, followed by a search 
for solutions to the system of Maxwell's equations in a regular inhomogeneous waveguide. Since in the process of solving subproblem 2 we encounter similar problems, then, guided by the principle of unification, it is advisable to applying for a unified approach to the transformation of physical areas. Note, that transformation methods should take into account the arbitrary shape of the injection contacts.

For "bonding" solutions on the interfaces of subdomains, it needs to use the projection boundary conditions (12).

To search for the components of the electromagnetic field in the $V_{\text {II }}$ region, we use the conformal mapping of its section in the XOY plane to a rectangle (an algorithm similar to (16-18) is used). This approach allows us to turn the section of the irregular waveguide $V_{\mathrm{II}}$ into the regular inhomogeneous waveguide $\widetilde{V}_{\mathrm{II}}$.

The statement of the problem (10-11) in the new coordinate system $(\tilde{x}=\tilde{x}(x, y), \tilde{y}=\tilde{y}(x, y), z)$ for $T E$ modes $\left(E_{x}=0\right)$ takes the following form. We need to find solutions of the Maxwell's equations system:

$$
\left\{\begin{array}{c}
\frac{\partial H_{z}}{\partial \widetilde{x}} \frac{\partial \widetilde{x}}{\partial y}+\frac{\partial H_{z}}{\partial \widetilde{y}} \frac{\partial \widetilde{y}}{\partial y}-\frac{\partial H_{y}}{\partial z}=0, \\
\frac{\partial H_{x}}{\partial z}-\frac{\partial H_{z}}{\partial \widetilde{x}} \frac{\partial \widetilde{x}}{\partial x}-\frac{\partial H_{z}}{\partial \widetilde{y}} \frac{\partial \widetilde{y}}{\partial x}=i \omega \varepsilon_{a v} \varepsilon_{0} E_{y} \\
\frac{\partial H_{y}}{\partial \widetilde{x}} \frac{\partial \widetilde{x}}{\partial x}+\frac{\partial H_{y}}{\partial \widetilde{y}} \frac{\partial \widetilde{y}}{\partial x}-\frac{\partial H_{x}}{\partial \widetilde{x}} \frac{\partial \widetilde{x}}{\partial y}-\frac{\partial H_{x}}{\partial \widetilde{y}} \frac{\partial \widetilde{y}}{\partial y}= \\
=i \omega \varepsilon_{a v} \varepsilon_{0} E_{z}, \\
\frac{\partial E_{z}}{\partial \widetilde{x}} \frac{\partial \widetilde{x}}{\partial y}+\frac{\partial E_{z}}{\partial \widetilde{y}} \frac{\partial \widetilde{y}}{\partial y}-\frac{\partial E_{y}}{\partial z}=-i \omega \mu_{0} H_{x} \\
\frac{\partial E_{z}}{\partial \widetilde{x}} \frac{\partial \widetilde{x}}{\partial x}+\frac{\partial E_{z}}{\partial \widetilde{y}} \frac{\partial \widetilde{y}}{\partial x}=i \omega \mu_{0} H_{y}, \\
\frac{\partial E_{y}}{\partial \widetilde{x}} \frac{\partial \widetilde{x}}{\partial x}+\frac{\partial E_{y}}{\partial \widetilde{y}} \frac{\partial \widetilde{y}}{\partial x}=-i \omega \mu_{0} H_{z}
\end{array}\right.
$$

where

$$
E_{y}=E_{y}(\tilde{x}, \tilde{y}, z)
$$$$
E_{z}=E_{z}(\tilde{x}, \tilde{y}, z)
$$

$H_{x}=H_{x}(\tilde{x}, \tilde{y}, z), \quad H_{y}=H_{y}(\tilde{x}, \tilde{y}, z), H_{z}=H_{z}(\tilde{x}, \tilde{y}, z)$

- required functions, which determine the components of EMW in the domain $V_{I I}$ under the conditions $\left.\frac{\partial H_{x}}{\partial \zeta}\right|_{S_{\perp}}=0$

$\left(S_{\perp}-\right.$ a contour of the cross-section of the waveguide region $\left.V_{\mathrm{II}}\right)$.

The boundary conditions determine the form of the desired functions of the problem as follows:

$$
\begin{gathered}
E_{x}=0, \\
H_{x}=\sum_{n} \sum_{m} \widetilde{H}_{n m}^{\tilde{x}+}(\tilde{x}) \cos \left(\frac{\pi n}{w}\left(\tilde{y}+\frac{w}{2}\right)\right) \cos \left(\frac{\pi m}{L_{B}} z\right), \\
E_{y}=\sum_{n} \sum_{m} \widetilde{E}_{n m}^{\tilde{y}+}(\tilde{x}) \cos \left(\frac{\pi n}{w}\left(\tilde{y}+\frac{w}{2}\right)\right) \sin \left(\frac{\pi m}{L_{B}} z\right),
\end{gathered}
$$

(C) Bomba A. Ya., Moroz I. P., Boichura M.V., 2021 DOI 10.15588/1607-3274-2021-1-2

$$
\begin{aligned}
H_{y} & =\sum_{n} \sum_{m} \widetilde{H}_{n m}^{\tilde{y}+}(\tilde{x}) \sin \left(\frac{\pi n}{w}\left(\tilde{y}+\frac{w}{2}\right)\right) \cos \left(\frac{\pi m}{L_{B}} z\right), \\
E_{z} & =\sum_{n} \sum_{m} E_{n m}^{z+}(\tilde{x}) \sin \left(\frac{\pi n}{w}\left(\tilde{y}+\frac{w}{2}\right)\right) \cos \left(\frac{\pi m}{L_{B}} z\right), \\
H_{z} & =\sum_{n} \sum_{m} \tilde{H}_{n m}^{z+}(\tilde{x}) \cos \left(\frac{\pi n}{w}\left(\tilde{y}+\frac{w}{2}\right)\right) \sin \left(\frac{\pi m}{L_{B}} z\right) .
\end{aligned}
$$

Note that functions (32) describe the process of EMW propagation along the $\mathrm{OX}$ axis. The components of an electromagnetic wave propagating in the opposite direction have a similar form. Substituting (32) into (31) turns the system of partial differential equations (31) into a system of ordinary differential equations:

$$
\begin{aligned}
& \int_{-\frac{w}{2}}^{\frac{w}{2}}\left(\sum _ { n } \left(\frac{d \widetilde{H}_{m n}^{z+}}{\partial \widetilde{x}} \frac{\partial \tilde{x}}{\partial y} \cos \left(\beta_{n}(\tilde{y})\right)-\frac{\pi n}{w} \widetilde{H}_{m n}^{z+} \frac{\partial \tilde{y}}{\partial y} \sin \left(\beta_{n}(\tilde{y})\right)-\right.\right. \\
& \left.\left.-\frac{\pi m}{L_{B}} \widetilde{H}_{m n}^{\tilde{y}+} \sin \left(\beta_{n}(\tilde{y})\right)\right), \sin \left(\beta_{k}(\tilde{y})\right)\right) d \tilde{y}=0 ; \\
& \int_{-\frac{w}{2}}^{\frac{w}{2}}\left(\sum _ { n } \left(-\frac{d \tilde{H}_{m n}^{z+}}{\partial \widetilde{x}} \frac{\partial \widetilde{x}}{\partial x} \cos \left(\beta_{n}(\tilde{y})\right)+\right.\right. \\
& +\frac{\pi n}{w} \widetilde{H}_{m n}^{z+} \frac{\partial \tilde{y}}{\partial x} \sin \left(\beta_{n}(\tilde{y})\right)-\frac{\pi m}{L_{B}} \widetilde{H}_{m n}^{\tilde{x}+} \cos \left(\beta_{n}(\tilde{y})\right)- \\
& \left.\left.-i \omega \varepsilon_{a v} \varepsilon_{0} \widetilde{E}_{m n}^{\tilde{y}+} \cos \left(\beta_{n}(\tilde{y})\right)\right), \cos \left(\beta_{k}(\tilde{y})\right)\right) d \widetilde{y}=0 ; \\
& \int_{-\frac{w}{2}}^{\frac{w}{2}}\left(\sum _ { n } \left(\frac{d \tilde{H}_{m n}^{\tilde{y}+}}{\partial \widetilde{x}} \frac{\partial \tilde{x}}{\partial x} \sin \left(\beta_{n}(\tilde{y})\right)+\right.\right. \\
& +\frac{\pi n}{w} \widetilde{H}_{m n}^{\tilde{y}+} \frac{\partial \widetilde{y}}{\partial x} \cos \left(\beta_{n}(\tilde{y})\right)-\frac{d \tilde{H}_{m n}^{\widetilde{x}+}}{\partial \widetilde{x}} \frac{\partial \widetilde{x}}{\partial y} \cos \left(\beta_{n}(\tilde{y})\right)+ \\
& \left.+\frac{\pi n}{w} \widetilde{H}_{m n}^{\widetilde{x}+} \frac{\partial \widetilde{y}}{\partial y} \sin \left(\beta_{n}(\tilde{y})\right)-i \omega \varepsilon_{a v} \varepsilon_{0} \widetilde{E}_{m n}^{z+} \sin \left(\beta_{n}(\tilde{y})\right)\right), \\
& \left.\sin \left(\beta_{k}(\tilde{y})\right)\right) d \widetilde{y}=0 \\
& \int_{-\frac{w}{2}}^{\frac{w}{2}}\left(\sum _ { n } \left(\frac{d \widetilde{E}_{m n}^{z+}}{\partial \widetilde{x}} \frac{\partial \widetilde{x}}{\partial y} \sin \left(\beta_{n}(\widetilde{y})\right)+\frac{\pi n}{w} \widetilde{E}_{m n}^{z+} \cos \left(\beta_{n}(\tilde{y})\right)-\right.\right. \\
& -\frac{\pi m}{L_{B}} \widetilde{E}_{m n}^{\tilde{y}+} \cos \left(\beta_{n}(\widetilde{y})\right)+ \\
& \left.\left.+i \omega \mu_{0} \widetilde{H}_{m n}^{\widetilde{x}+} \cos \left(\beta_{n}(\tilde{y})\right)\right), \cos \left(\beta_{k}(\tilde{y})\right)\right) d \widetilde{y}=0 ;
\end{aligned}
$$




$$
\begin{aligned}
& \int_{-\frac{w}{2}}^{\frac{w}{2}}\left(\sum _ { n } \left(\frac{d \widetilde{E}_{m n}^{z+}}{\partial \widetilde{x}} \frac{\partial \widetilde{x}}{\partial x} \sin \left(\beta_{n}(\tilde{y})\right)+\frac{\pi n}{w} \widetilde{E}_{m n}^{z+} \frac{\partial \widetilde{y}}{\partial x} \cos \left(\beta_{n}(\tilde{y})\right)-\right.\right. \\
& \left.\left.-i \omega \mu_{0} \widetilde{H}_{m n}^{\tilde{y}+} \sin \left(\beta_{n}(\tilde{y})\right)\right), \sin \left(\beta_{k}(\tilde{y})\right)\right) d \widetilde{y}=0 ; \\
& \int_{w}^{\frac{w}{2}}\left(\sum _ { n } \left(\frac{d \widetilde{E}_{m n}^{\tilde{y}+}}{\partial \widetilde{x}} \frac{\partial \widetilde{x}}{\partial x} \cos \left(\beta_{n}(\tilde{y})\right)-\frac{\pi n}{w} \widetilde{E}_{m n}^{\widetilde{y}+} \frac{\partial \widetilde{y}}{\partial x} \sin \left(\beta_{n}(\tilde{y})\right)+\right.\right. \\
& \left.\left.+i \omega \mu_{0} \widetilde{H}_{m n}^{z+} \cos \left(\beta_{n}(\tilde{y})\right)\right), \cos \left(\beta_{k}(\tilde{y})\right)\right) d \tilde{y}=0,
\end{aligned}
$$

where $\beta_{n}(\tilde{y})=\frac{\pi n}{w}\left(\tilde{y}+\frac{w}{2}\right), E_{m n}^{\tilde{y}+}(\tilde{x}), E_{m n}^{z+}(\tilde{x}), H_{m n}^{\tilde{x}+}(\tilde{x})$, $H_{m n}^{\tilde{y}+}(\tilde{x}), H_{m n}^{z+}(\tilde{x})-$ desired complex functions.

The system of differential equations (33) is supplemented by initial conditions of the form (12). Moreover, in the $x=0$ plane, the given is the value of the complex functions $E_{m n}^{\widetilde{y}+}(0), E_{m n}^{z+}(0), H_{m n}^{\widetilde{x}+}(0), H_{m n}^{\widetilde{y}+}(0), H_{m n}^{z+}(0)$, determined from the boundary conditions of the form:

$$
\begin{gathered}
\iint_{S_{\perp}}\left(\left(\left(E_{10}^{1+}+E_{10}^{1-}\right) \sin \left(\frac{\pi}{L_{B}} z\right)+\sum_{n} E_{1 n}^{1-} \cos \left(\frac{\pi n}{d}\left(y+\frac{d}{2}\right)\right) \times\right.\right. \\
\left.\left.\times \sin \left(\frac{\pi}{L_{B}} z\right)-\sum_{n}\left(\widetilde{E}_{1 n}^{2+}(0)+\widetilde{E}_{1 n}^{2-}(0)\right) \cos \left(\frac{\pi n}{w}\left(y+\frac{w}{2}\right)\right) \cdot(34)\right), \cos \left(\frac{\pi k}{d}\left(y+\frac{d}{2}\right)\right) \sin \left(\frac{\pi}{L_{B}} z\right)\right) d s=0,
\end{gathered}
$$

where $S_{\perp}=\left\{(y, z):-\frac{d}{2} \leq y \leq \frac{d}{2}, 0 \leq z \leq L_{B}\right\}, \quad E_{1 n}^{2+}(0)$, $E_{1 n}^{2-}(0)$ - the amplitude incident on the 2 nd boundary (in the plane $x=h$ ) and reflected from the 2 nd boundary of the modes, and the value $E_{1 n}^{2+}(0)$ is calculated on the basis of (34), $E_{1 n}^{2-}(0)$ is found by solving a system of equations similar to (33) with the initial conditions given for $x=h$ $\left(E_{m n}^{\tilde{y}-}(h), E_{m n}^{z-}(h), H_{m n}^{\tilde{x}-}(h), H_{m n}^{\tilde{y}-}(h), H_{m n}^{z-}(h)\right)$, which in turn are determined from equations similar to (34).

4) The microwave switch must, under absence of a control current, ensure the maximum transmission of EMW energy and the minimum transmission of energy if it available. It is proposed to obtain the optimal characteristics of the system under study based on the fulfillment of the condition

$$
T(\widetilde{w}, \tilde{h}, j=0)-T(\widetilde{w}, \tilde{h}, j \neq 0) \rightarrow \max .
$$

The geometrical dimensions $((d-\widetilde{w})-$ width, $\tilde{h}-$ depth) of the injecting contacts here have the meaning of parameters, the values of which are set by the method of direct enumeration of possible options (determination of (C) Bomba A. Ya., Moroz I. P., Boichura M.V., 2021 DOI 10.15588/1607-3274-2021-1-2 ranges of optimal values on the basis of "trial measurements" with subsequent refinement). In this case, the shape of the profile of the contact areas is set by specifying the functions $y=g_{p}(x, \widetilde{w}, \widetilde{h}), y=g_{n}(x, \widetilde{w}, \widetilde{h})$ and additional restrictions are imposed on the size of the region $G: 0 \leq \tilde{w} \leq d, 0 \leq \tilde{h} \leq h+b$.

\section{EXPERIMENTS}

On the basis of the proposed mathematical model, the algorithm has been developed that allows a series of computer examinations to be carried out. The input data for the algorithm are the parameters of the EMW (wave of the $T E_{10}$ type, $\left.E_{0}=1, f=36 G G z\right)$, the dimensions of the waveguide section $\left(L_{a}=7.2 \mathrm{~mm}, L_{b}=3.4 \mathrm{~mm}\right)$, the repetition period of the elements of the p-i-n-structure $(d \approx 30$ $\mu m)$, the thickness of the structure $(h+b=80 \mu m)$, the physical characteristics of silicon (are shown lower), the accuracy of the subtasks solving of each stage $(\sim)$.

The algorithm describing the iterative process of the problem solving of reducing the physical region to the canonical form, the diffusion-drift problem, the electrodynamic problem with the analysis of the information received at the each stage, consists of the following steps.

The boundary of the studied region $G^{\prime}$ is set using functions $y=g_{n}(x, w, h)$ and values $w, h, b, d, m$ and $l-$ the partitioning parameters of the regions (Fig. 3); the accuracy $\delta$, the values $\tilde{x}_{*}$ on the segment $A B$ and $\tilde{x}^{*}-$ on $C D$ (without loss of generality, we assume $\tilde{x}_{*}=0, \tilde{x}^{*}=1$ ), the initial approximations of the coordinates of the boundary, internal nodes and conformal invariants (using formulas (19-20) and (22) respectively) are set; we calculate $\Delta \widetilde{x}=\frac{\tilde{x}^{*}-\tilde{x}_{*}}{m+1}$.

The partitioning step $\Delta \widetilde{y}$ of the domain $\widetilde{G}^{\prime \lambda}$, the parameter $Q$, the coordinates of the internal nodes, the conformal invariants, and the boundary nodes are consistently refined according to the formulas $\Delta \tilde{y}=\frac{\Delta \tilde{x}}{\lambda_{c}}$, $Q=(l+1) \Delta \widetilde{y}$, as well as in accordance with (19-22).

If the conditions for completing the iterative process are not fulfilled [13], then the partitioning step of the region $\widetilde{G}^{\prime \lambda}$ are refined, otherwise, a grid is constructed that corresponds to an element of the integrated $\mathrm{p}-\mathrm{i}$-n-structure with the help of nodal points $\left(x_{i, j}, y_{i, j}\right)$ ( $i=\overline{-m-1, m+1}, \quad j=\overline{0, n+1}$ ) taking into account the corresponding symmetry $\quad\left(\tilde{x}_{i-m-1, j}=\tilde{x}_{m+1-i, j}\right.$, $\left.\tilde{y}_{i-m-1, j}=\tilde{y}_{m+1-i, j}\right)$.

Then, by point-to-point fixing of values, the system of linear algebraic equations (28) is solved.

The obtained distribution of charge carriers in the subregions $G_{1}$ and $G_{2}$ are averaged and used to determine the dielectric constant (9) of the active region. 
The next step is the solution of the electrodynamic problem (33-34). The equations of type (34) form a system of linear algebraic equations, which are jointly solved with systems of equations of type (33). The solutions are obtained as a result of an iterative process of solving a system of equations of type (33-34). And the classical computational methods of Runge-Kutta and Gauss are used. The convergence of the process is proved experimentally.

The general idea of the algorithm for determining the optimal configuration of the shape and the size of the injecting contacts is to sort through all possible sets of values $w \in\left[w_{L}, w_{R}\right]$ and $h, \in\left[h_{B}, h_{T}\right]$ with steps $\Delta w=\left(w_{R}-w_{L}\right) / m_{w}$ and $\Delta h=\left(h_{T}-h_{B}\right) / m_{h}$, at which the functional (35) takes the maximum value, where $w_{L}$, $w_{R}, h_{B}, h_{T}$ are the predefined left, right, lower and upper boundaries of the enumeration sections of the injecting contact configurations, $m_{w}, m_{h}$ is the number of split points of the segments. The corresponding iterative step of finding the energy transmission coefficient in the switch is reduced to the sequential solution of subproblems (19-22) (for conformal mapping), (28) (for finding the distribution of charge carriers concentration), averaging of the concentration separately in regions $G_{1}$ and $G_{2}$, calculating the permittivity by the formula (9), solving a system of equations of type (33-34) and functional (35).

\section{RESULTS}

We give two examples of mapping the grid of nodes of the canonical domain to the physical domain of the problem. In the case, when the boundary of the contact region ( $\mathrm{p}-\mathrm{i}-$ and $\mathrm{n}-\mathrm{i}-$ junctions) is determined by the parameters $w=2, h=2, b=8, d=4$ (relative units are used here) and function $\mathrm{y}=0.5(x(d-w) / h+w)$, at the number of partition nodes $m=100, l=400$ and $\tilde{x}_{*}=0, \quad \tilde{x}^{*}=1$, the grid shown in Fig. 5a (wedge-shaped contact) is obtained. If the shape of the contour $C D$ is described by a function of the form $y=0.5 w-\sqrt{1-x^{2}\left(1-(0.5(d-w)-1)^{2}\right) / h^{2}}+1 \quad$ and $l=464$, the grid of nodes is obtained as displayed in Fig. $5 \mathrm{~b}$. The results of similar calculations for the crosssection $G_{1}$ of the active region $V_{\mathrm{II}}$ at $m=50, l=36$ and $m=50, \quad l=43$ are shown in Fig. $5 \mathrm{c}$ and Fig. $5 \mathrm{~d}$ respectively.

Fig. 6 shows the calculations results of the charge carriers concentration distribution for the case of determining section $C D$ in the form of a straight line segment $y=0.5(x(d-w) / h+w)$ for the following input data: $m=100$, $l=400, \quad d=0.003024 \mathrm{~cm}, \quad b=0.0070928 \mathrm{~cm}$, $w=0.0012096 \mathrm{~cm}$,

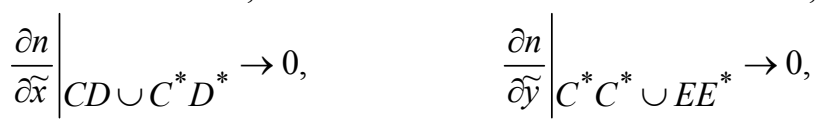

$\gamma_{n}=10^{5} \mathrm{~cm}^{-1}, \quad \gamma_{p}=2 \cdot 10^{5} \mathrm{~cm}^{-1}, \tau=10^{-4} \mathrm{~s}, J_{\min }=10^{-3} \mathrm{~A} / \mathrm{cm}^{2}$, $J_{\max }=10 \mathrm{~A} / \mathrm{cm}^{2}, D_{p}=25 \mathrm{~cm}^{2} / \mathrm{s}, D_{n}=35 \mathrm{~cm}^{2} / \mathrm{s}$.

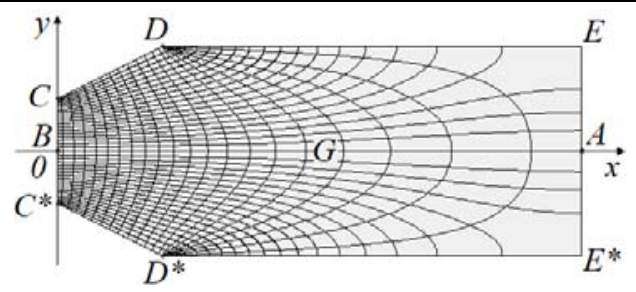

a

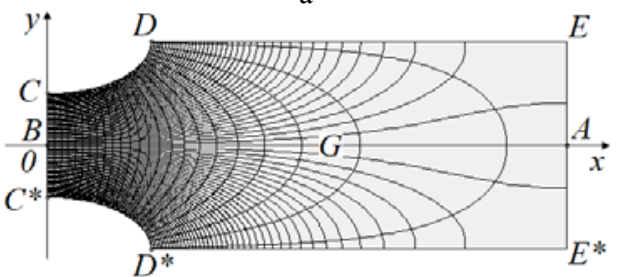

b

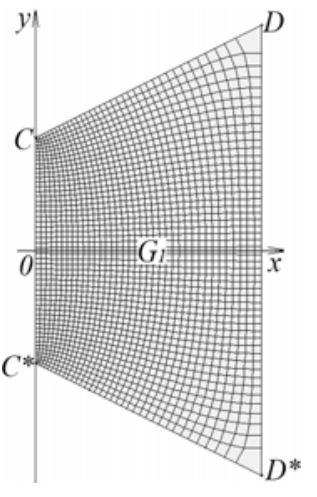

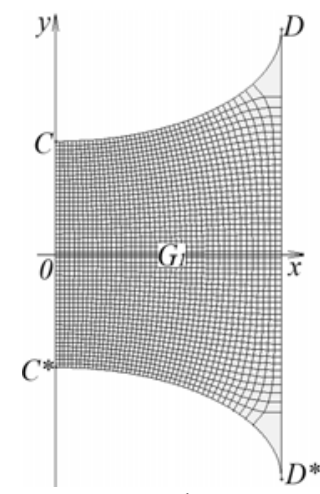

d
Figure 5 - Examples of computational grids for an element of the integrated p-i-n-structure $G(\mathrm{a}, \mathrm{b})$ and the cross-section $G_{1}$ of the region $V_{\mathrm{II}}(\mathrm{c}, \mathrm{d})$ at the form of a contact in the form of a straight line segment (contact region of a wedge-shaped shape) $(a, c)$ and an ellipse section $(b, d)$

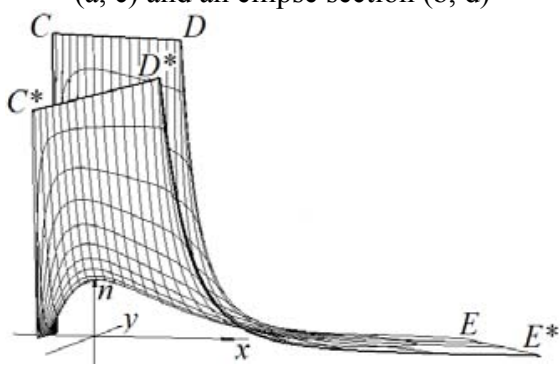

a

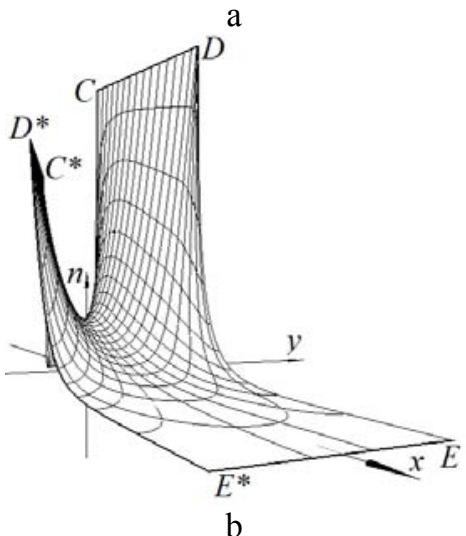

Figure 6 - Distribution of the concentration of charge carriers in the active region of $\mathrm{p}$-i-n-structures in various angles of view (wedge-shaped contact region) 
For a given shape of the contact region $(y=0.5(x(d-w) / h+w)$ wedge-shaped contact), the dependences of the average concentration of electron-hole plasma $\left(\langle n\rangle=\frac{1}{V_{G_{i}}} \iint_{V_{G_{i}}} n(x, y) d x d y\right)$, the real and imaginary components of the dielectric constant (9) of the active region of the integrated $\mathrm{p}$-i-n-structure on the value of the
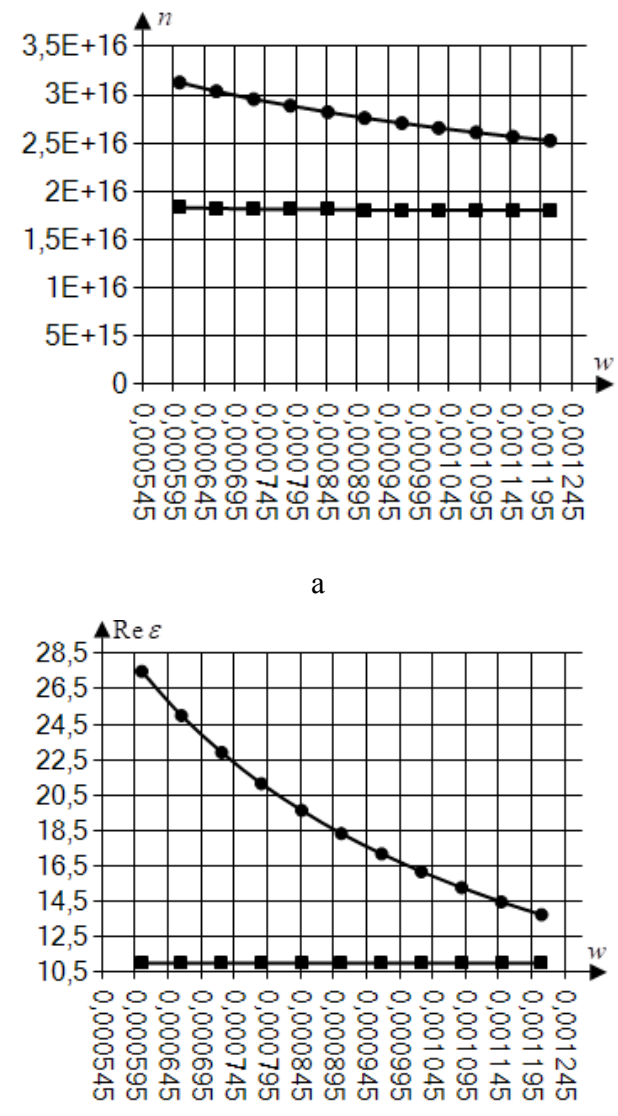

c

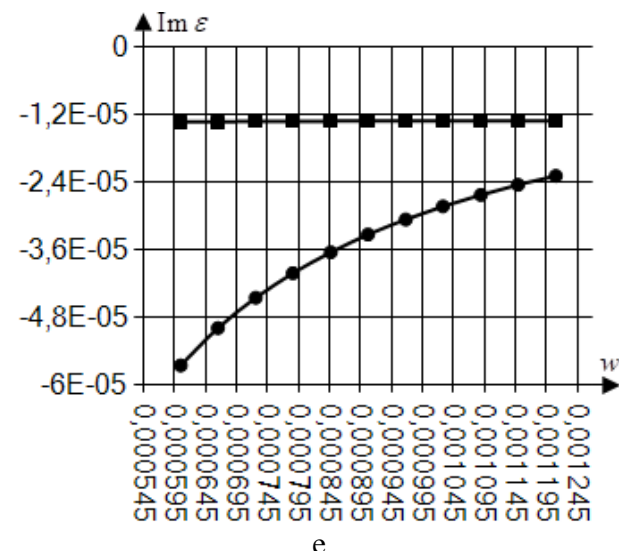

parameters $h, w, d$ are shown in Fig. 7 (parameters used: $\varepsilon_{L}=11, \quad c=3 \cdot 10^{8} \mathrm{~m} / \mathrm{s}, \quad e=1.6 \cdot 10^{-19} \mathrm{C}, \quad \varepsilon_{0}=8.85 \cdot 10^{-12} \mathrm{~F} / \mathrm{m}$, $\omega=226.95 \cdot 10^{9} \mathrm{rad} / \mathrm{s}, \quad v_{n}=25 \cdot 10^{12} \mathrm{~s}^{-1}, \quad v_{p}=20 \cdot 10^{12} \mathrm{~s}^{-1}$, $\left.m_{n}=9.646 \cdot 10^{-31} \mathrm{~kg}, m_{p}=5.096 \cdot 10^{-31} \mathrm{~kg}\right)$.

Typical $T(w, h, j)$ behavior depending on the values of the parameters $h, w, d$ and the contact shape is shown in Fig. 8.
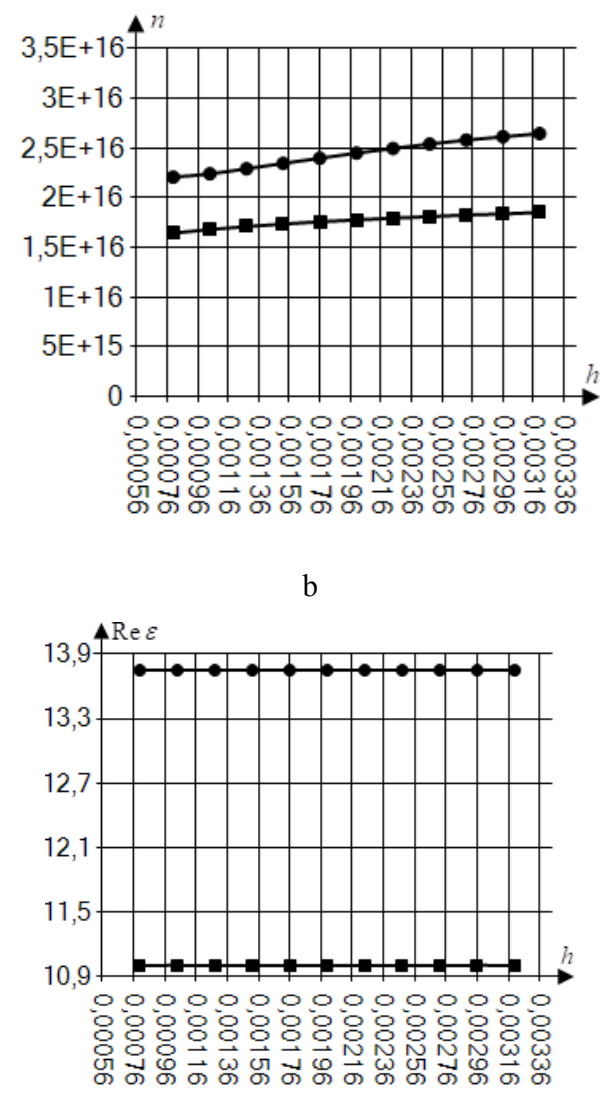

d

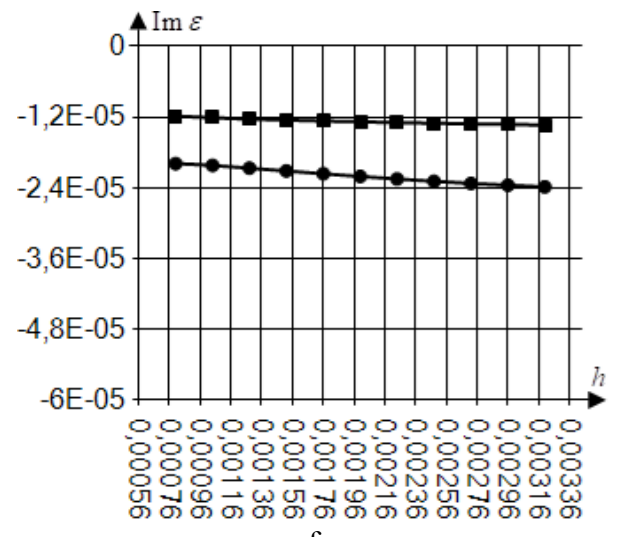

$\mathrm{f}$

Figure 7 - Dependences of the average plasma concentration $(a, b)$, the real (c, d) and imaginary (e, f) parts of the dielectric constant of the active region on the parameters $w(h=0.0024)(\mathrm{a}, \mathrm{c}, \mathrm{e})$ and $h(w=0.0012096)(\mathrm{b}, \mathrm{d}, \mathrm{f})$ in the $G_{1}$ (line with circle markers) and $G_{2}$ (line with square markers) domains 


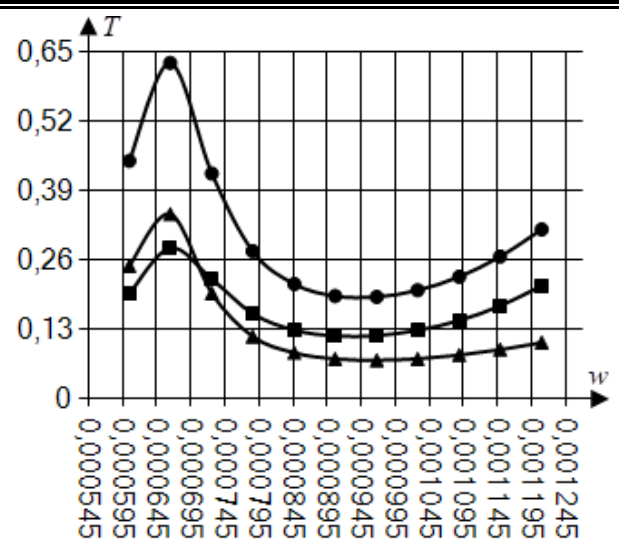

a

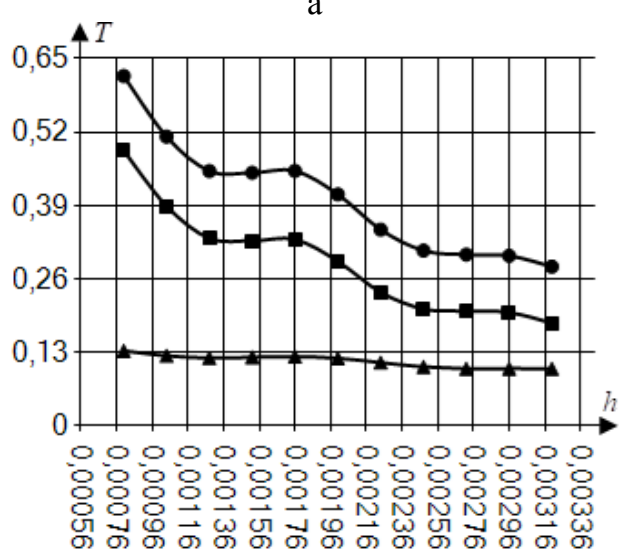

$\mathrm{b}$

Figure 8 - Dependences of the EMW transmission coefficient in the absence (line with circle markers) and presence (line with square markers) of a control current on the parameters $w$ $(h=0.0024)$ (a) and $h(w=0.0012096)(\mathrm{b})$; their difference is represented by a line with triangle markers

In the specific case of wedge-shaped contact shape, the following optimal values were obtained: the base of the wedge is $d-\widetilde{w} \approx 6.5 \mu \mathrm{m}$, and the height is $\widetilde{h} \approx 20 \mu \mathrm{m}$.

\section{DISCUSSION}

The numerical experiments results unquestioningly confirm the importance of the proposed approach of the conformal transformation of the physical region (active region of the integrated $\mathrm{p}$-i-n-structure), which makes it possible to extend traditional modeling methods to cases of complex regions. In addition, there is an opportunity to optimize the characteristics of the switches on the integrated tape-type p-in-structures. We also note that the proposed numerical procedure of the conformal mapping method provides an optimal choice of the computational grid. In this case, the ratio between the parameters of dividing curvilinear quadrangular regions can be carried out in a semi-automatic mode, for example, when the corresponding constituent rectangles approach the squares.

The obtained results are consistent with the results of the studies, which are reflected in [4-6]. Note that the proposed algorithm differs from the existing ones in the accuracy of the model and universality, which makes it possible to use it, in particular, to solve the optimization problem.
Undoubtedly, the proposed approach can be easily transferred to the cases of inhomogeneous media, media with pronounced spatiality, cases of taking into account the dynamics of the medium, in particular, due to the inverse influence of the characteristics of the process on the characteristics of the medium [17].

Note: this task on conformal mappings can also be used to find the distribution of the potential lines $\varphi$ and the field lines $\psi(\widetilde{x}$ corresponds to the equipotential lines $\varphi=\varphi(x, y)$, $\tilde{y}$ corresponds to the field lines $\psi=\psi(x, y))$.

\section{CONCLUSIONS}

As a result of the present research, mathematical and computer models of the process of interaction of microwave EMW with electron-hole plasma of the active region of integrated p-i-n-structures are obtained. The mathematical model allows to obtain a number of important characteristics of the switch: the EMW transmission coefficient through the switching system at a high / low level of control current (the structure insertion losses in the waveguide), the dielectric permittivity of the active region of p-i-n-structures, characterizes its electrodynamic properties; the distribution of charge carriers in the active region is established as a result of their injection from $\mathrm{p}-\mathrm{i}$ and $\mathrm{n}-\mathrm{i}$ junctions under the action of a control current. The obtained characteristics are consistent with the data obtained using the one-dimensional model of the process of ambipolar diffusion of the model of averaging the electrodynamic characteristics of layers of the integrated structure.

The scientific novelty of obtained results is that the proposed mathematical model takes into account the structural features of the injected contacts of the integrated circuit, which in essence is a p-i-n-structure, and in a certain sense is universal. Such a result was achieved by using the method of conformal mappings to reduce the physical areas of the problem to a canonical form. The approach proposed in this paper allows to carry out a procedure for optimizing the shape and geometric dimensions of an element of a p-i-n-structure and injection contacts, in particular, with arbitrary sets of input data of the switching system (operating frequency, type of semiconductor material, etc.).

Prospects for further research. The constructed mathematical model is characterized by an increased level of detail of the processes in the system under study compared to existing models and, accordingly, an increased level of complexity, which, in turn, requires the attraction of significant resources of computing systems. Therefore, this work provides an example of the application of the developed optimization algorithm for only one type of (wedge-shaped) injection contacts. The general optimization procedure requires a separate, more detailed study. In addition, the questions of the heating influence of the electron-hole plasma of the p-in-structure by the control current and of the effect of the shape and geometric dimensions of the injected contacts on the heat balance of the system remain open. Obviously, these factors must be taken into account when solving the optimization problems of microelectronics.

\section{REFERENCES}

1. Pozar M. Microwave Engineering. New York, Wiley, 2010, 736 p.

2. Kwok K. Complete Guide to Semiconductor Devices. New York, Wiley-Interscience, 2002, 740 p. 
3. Mortenson K. E., Borrego J. M., Bakeman P. E., Gutmann R. J. Microwave silicon windows for high-power broad-band switching applications, IEEE J. Solid-State Circuits, 1969, Vol. 4, No. 6, pp. 413-421.

4. Koshevaya S. V. Kishenko Ya. I., Smoilovskii M. I., and Trapezon V. A. Fast wideband modulators on p-i-n structures, Izv. Vyssh Uchebn. Zaved., Radioelektron.; Radioelectron. Commun. Syst., 1989, No. 10, pp. 14-23.

5. Koshevaya S., Moroz I., Grimalsky V., Tecpoyolt-Torres M., Escobedo-Alatorre J. Comparison of Volume and Integrated P-I-N Modulators in Millimeter Wave Range, International Journal of Infrared and Millimeter Waves, 2005, Vol. 26, No. 3, pp. 387-408.

6. Sze S., Kwok K. Physics of Semiconductor Devices. New York, Wiley-Interscience, 2006, 815 p.

7. Grundmann M. The Physics of Semiconductors. Berlin, New York, Springer, 2006, 689 p.

8. Collin R. E. Foundations for microwave engineering. New York, Wiley IEEE Press, 2001, 944 p.

9. Shestopalov V. P., Kirilenko A. A., and Rud' L. A. Resonance Wave Scattering, Vol. 2: Waveguide Discontinuities. Kiev, Naukova Dumka, 1986, 216 p. [in Russian].

10. Il'insky A. S., Slepjan A. Ja., Slepjan G. Ja. Propagation, diffraction and dissipation of electromagnetic waves. London, UK, The IEE and Peter Peregrinous Ltd. Publ., Electromagnetic Waves (Series 36), 1993, $275 \mathrm{p}$

11. Samarskii A. A. The Theory of Difference Schemes. Boca Raton, CRC Press, 2001, 786 p. DOI: 10.1201/9780203908518.
12. Fuchs B. A., Shabat B. V. Functions of a complex variable and some of their applications, Pergamon Press, 1964, 458 p. DOI: 10.1016/C2013-0-01663-5.

13. Bomba A. Ya., Kashtan S. S., Skopetskii V. V. Nonlinear Inverse Boundary-Value Problems of Conformal Mapping with a Controlling Potential, Cybernetics and Systems Analysis, 2004, Vol. 40 (1), pp. 58-65. DOI: 10.1023/B: CASA.0000028100.70341.57.

14. Bomba A. Ya., Kuzlo M. T., Michuta O. R., Boichura M. V. On a method of image reconstruction of anisotropic media using applied quasipotential tomographic data, Mathematical Modeling and Computing, 2019, Vol. 6 (2), pp. 211-219. DOI: $10.23939 / \mathrm{mmc} 2019.02 .211$

15. Katsenelenbaum B. Marcader del Rio L., Perreyaslavets M., Sorolla Auza M., Thumm M. Theory of Nonuniform Waveguides, IEE Series, London, 1998, 272 p. DOI: 10.1049/PBEW044E.

16. Bomba A., Moroz I. Mathematical Modeling of Electromagnetic Fields in Irregular Waveguide, 2019 IEEE 20th International Conference on Computational Problems of Electrical Engineering (CPEE), 15-18 Sept. 2019. Lviv-Slavske, 2019, pp. 1-4. DOI: 10.1109/CPEE47179.2019. 8949094.

17. Bulavatsky V. M. Fractional Differential Analog of Biparabolic Evolution Equation and Some Its Applications, Cybernetics and Systems Analysis, 2016, Vol. 52, pp. 737-747. DOI: $10.1007 / \mathrm{s} 10559-016-9875-5$

Received 12.04.2020. Accepted 15.02.2021.

УДК 519.6:621.382.233

\section{ОПТИМІЗАЦІЯ ФОРМИ І РОЗМІРУ ІНЖЕКТУЮЧИХ КОНТАКТІВ ІНТЕГРАЛЬНИХ Р-І-N-СТРУКТУР НА ОСНОВІ} ВИКОРИСТАННЯ МЕТОДУ КОНФОРМНИХ ВІДОБРАЖЕНЬ

Бомба А. Я. - д-р техн. наук, професор кафедри комп'ютерних наук та прикладної математики Національного університету водного господарства та природокористування, Рівне, Україна.

Мороз І. П. - канд. физ.-мат. наук, доцент кафедри інформатики та прикладної математики Рівненського державного гуманітарного університету, Рівне, Україна.

Бойчура М. В. - м.н.с. науково-дослідної частини Національного університету водного господарства та природокористування, Рівне, Україна.

Актуальність. P-i-n-діоди широко використовуються у техніці надвисоких частот для управління електромагнітним полем. Керування полем здійснюється за рахунок формування в області власного напівпровідника (і-області) електронно-діркової плазми під дією керуючого струму. Розвиток керуючих пристроїв на p-i-n-діодах привів до появи інтегральних р-i-n-структур різних типів, характеристики яких (наприклад, швидкодія, рівень комутованої потужності тощо) перевищують аналогічні характеристики об’ємних діодів. Властивості p-i-n-структур визначають ряд процесів: дифузійно-дрейфовий процес перенесення зарядів, рекомбінаційно-генераційні, теплові, інжекції тощо. Очевидно, що зазначені процеси повинні враховуватись (знаходити відображення) у математичній моделі системи комп'ютерного проектування керуючих пристроїв надвисокочастотних систем. Комплексне врахування процесів приводить до постановки складних задач. Одна із них - задача оптимізації форми, геометричних розмірів та розміщення інжектуючих контактів (активної області).

Мета. Полягає у розробці математичної моделі та відповідного їй програмного комплексу процесу взаємодії надвисокочастотних хвиль 3 електронно-дірковою плазмою в активній області напівпровідникових комутуючих поверхнево-орієнтованих інтегральних p-i-n-структур з контактами стрічкового типу для проведення процедури оптимізації форми та геометричних розмірів активної області.

Метод. Основна ідея розробленого алгоритму - застосування методу конформних відображень для приведення фізичної області задачі до канонічного вигляду з подальшим розв'язанням на даній області внутрішніх крайових задач для рівняння амбіполярної дифузії та хвильового рівняння чисельно-аналітичними методами (використано метод скінченних різниць, частинних областей із застосуванням проекційних граничних умов, аналог методу Гальоркіна). В основі оптимізаційного алгоритму лежить поетапне розв'язання (при заданих на кожному етапі формі та геометричних розмірах активної області) наступних задач: знаходиться розрахункова сітка вузлів для фізичних областей задачі, розраховується розподіл концентрації носіїв заряду в активній області, обчислюється коефіцієнт передачі енергії в досліджуваній системі, який входить в запропонований оптимізаційний функціонал. Екстремальні значення функціоналу знаходяться методом рівномірного пошуку.

Результати. Запропонована математична модель та відповідний результативний алгоритм оптимізації форми та геометричних розмірів активної області (і-області) інтегральних поверхнево-орієнтованих p-i-n-структур розширює інструментальну базу для проектування напівпровідникових схем надвисоких частот (аналогічних, наприклад, CST MICROWAVE STUDIO).

Висновки. Розроблено алгоритм оптимізації форми та геометричних розмірів активної області інтегральних поверхневоорієнтованих p-i-n-структур з заглибленими контактами, що призначені для комутації електромагнітних сигналів міліметрового діапазону. Універсальність алгоритму забезпечується застосуванням методу конформних відображень просторових областей. Розглянуто приклад застосування запропонованого алгоритму для пошуку оптимальних розмірів клиновидних (в поперечному розрізі) контактів кремнієвих структур.

КЛЮЧОВІ СЛОВА: метод конформних відображень, оптимізація параметрів, процес амбіполярної дифузії, хвильовий процес, комутатор електромагнітного поля надвисоких частот, p-i-n-структура. 


\section{УДК 519.6:621.382.233}

\section{ОПТИМИЗАЦИЯ ФОРМЫ И РАЗМЕРА ИНЖЕКЦИОННЫХ КОНТАКТОВ ИНТЕГРАЛЬНЫХ Р-І-N-СТРУКТУР НА} ОСНОВЕ ИСПОЛЬЗОВАНИЯ МЕТОДА КОНФОРМНЫХ ОТОБРАЖЕНИЙ

Бомба А. Я. - д-р техн. наук, профессор кафедры компьютерных наук и прикладной математики Национального университета водного хозяйства и природопользования, Ровно, Украина.

Мороз И. П. - канд. физ.-мат. наук, доцент кафедры информатики и прикладной математики Ровенского государственного гуманитарного университета, Ровно, Украина.

Бойчура М. В. - м.н.с. научно-исследовательского сектора Национального университета водного хозяйства и природопользования, Ровно, Украина.

\section{АННОТАЦИЯ}

Актуальность. P-i-n-диоды широко используются в технике сверхвысоких частот для управления электромагнитным полем. Управление полем осуществляется за счет формирования в области собственного полупроводника (і-области) электронно-дырочной плазмы под действием управляющего тока. Развитие управляющих устройств на p-i-n-диодах привел к появлению интегральных p-i-n-структур различных типов, характеристики которых (например, быстродействие, уровень коммутируемой мощности и т.д.) превышают аналогичные характеристики объемных диодов. Свойства p-i-n-структур определяют ряд процессов: диффузионно-дрейфовый процесс переноса зарядов, рекомбинационно-генерационные, тепловые, инжекции и тому подобное. Очевидно, что указанные процессы должны учитываться (находить отражение) в математической модели системы компьютерного проектирования управляющих устройств сверхвысокочастотных систем. Комплексный учет процессов приводит к постановке сложных задач. Одна из них - задача оптимизации формы, геометрических размеров и размещения инжекционных контактов (активной области).

Цель. Заключается в разработке математической модели и соответствующего ей программного комплекса процесса взаимодействия сверхвысокочастотных волн с электронно-дырочной плазмой в активной области полупроводниковых коммутирующих поверхностноориентированных интегральных p-i-n-структур с контактами ленточного типа для проведения процедуры оптимизации формы и геометрических размеров активной области.

Метод. Основная идея разработанного алгоритма - применение метода конформных отображений для приведения физической области задачи к каноническому виду с последующим решением на данной области внутренних краевых задач для уравнения амбиполярной диффузии и волнового уравнения численно-аналитическими методами (использован метод конечных разностей, частных областей с применением проекционных граничных условий, аналог метода Галеркина). В основе оптимизационного алгоритма лежит поэтапное решение (при заданных на каждом этапе форме и геометрическим размерам активной области) следующих задач: находится расчетная сетка узлов для физических областей задачи, рассчитывается распределение концентрации носителей заряда в активной области, вычисляется коэффициент передачи энергии в исследуемой системе, входящий в предложенный оптимизационный функционал. Экстремальные значения функционала находятся методом равномерного поиска.

Результаты. Предложенная математическая модель и соответствующий результативный алгоритм оптимизации формы и геометрических размеров активной области (i-области) интегральных поверхностно-ориентированных p-i-n-структур расширяет инструментальную базу для проектирования полупроводниковых схем сверхвысоких частот (аналогичных, например, CST MICROWAVE STUDIO).

Выводы. Разработан алгоритм оптимизации формы и геометрических размеров активной области интегральных поверхностноориентированных p-i-n-структур с углубленными контактами, предназначенных для коммутации электромагнитных сигналов миллиметрового диапазона. Универсальность алгоритма обеспечивается применением метода конформных отображений пространственных областей. Рассмотрен пример применения предложенного алгоритма для поиска оптимальных размеров клинообразных (в поперечном разрезе) контактов кремниевых структур.

КЛЮЧЕВЫЕ СЛОВА: метод конформных отображений, оптимизация параметров, процесс амбиполярной диффузии, волновой процесс, коммутатор электромагнитного поля сверхвысоких частот, p-i-n-структура.

\section{ЛІТЕРАТУРА / ЛИТЕРАТУРА}

1. Pozar M. Microwave Engineering / M. Pozar. - New York : Wiley, 2010. $-736 \mathrm{p}$

2. Kwok K. Complete Guide to Semiconductor Devices / K. Kwok. New York : Wiley-Interscience, 2002. - $740 \mathrm{p}$.

3. Microwave silicon windows for high-power broad-band switching applications / [K. E. Mortenson, J. M. Borrego, P.E. Bakeman, R. J. Gutmann] // IEEE J. Solid-State Circuits. - 1969. - Vol. 4. No. 6. - P. 413-421.

4. Koshevaya S. V. Fast wideband modulators on p-i-n structures [S. V. Koshevaya, Ya. I. Kishenko, M. I. Smoilovskii, and V. A. Trapezon] // Izv. Vyssh. Uchebn. Zaved., Radioelektron.; Radioelectron. Commun. Syst. - 1989. - No. 10. - P. 14-23.

5. Comparison of Volume and Integrated P-I-N Modulators in Millimeter Wave Range / [S. Koshevaya, I. Moroz, V. Grimalsky et al] // International Journal of Infrared and Millimeter Waves. 2005. - Vol. 26, No. 3. - P. 387-408.

6. Sze S. Physics of Semiconductor Devices / S. Sze, K. Kwok. - New York : Wiley-Interscience, 2006. $-815 \mathrm{p}$.

7. Grundmann M. The Physics of Semiconductors / M. Grundmann. Berlin, New York: Springer, 2006. - 689 p.

8. Collin R.E. Foundations for microwave engineering / R. E. Collin. New York : Wiley IEEE Press, 2001. - 944 p.

9. Shestopalov V. P. Resonance Wave Scattering, Vol. 2: Waveguide Discontinuities / V. P. Shestopalov, A. A. Kirilenko, and L. A. Rud'. - Kiev : Naukova Dumka, 1986. - 216 p. [in Russian].

10. Il'insky A. S. Propagation, diffraction and dissipation of electromagnetic waves / A. S. Il'insky, A. Ja. Slepjan, G. Ja. Slepjan. - London, UK : The IEE and Peter Peregrinous Ltd. Publ., Electromagnetic Waves (Series 36), 1993. - 275 p.
11. Samarskii A. A. The Theory of Difference Schemes A. A. Samarskii. - Boca Raton : CRC Press, 2001. - 786 p. DOI: 10.1201/9780203908518

12. Fuchs B.A. Functions of a complex variable and some of their applications / B. A. Fuchs, B. V. Shabat. - Pergamon Press, 1964. 458 p. DOI: $10.1016 /$ C2013-0-01663-5.

13. Bomba A. Ya. Nonlinear Inverse Boundary-Value Problems of Conformal Mapping with a Controlling Potential / A. Ya. Bomba, S. S. Kashtan, V. V. Skopetskii // Cybernetics and Systems Analysis. 2004. - Vol. 40 (1). - P. 58-65. DOI: 10.1023/B CASA.0000028100.70341.57.

14. On a method of image reconstruction of anisotropic media using applied quasipotential tomographic data / [A. Ya. Bomba, M. T. Kuzlo, O. R. Michuta, M. V. Boichura] // Mathematical Modeling and Computing. - 2019. - Vol. 6 (2). - P. 211-219. DOI: 10.23939/mmc2019.02.211.

15. Katsenelenbaum B. Theory of Nonuniform Waveguides [B. Katsenelenbaum, L. Marcader del Rio, M. Perreyaslavets et al]. - IEE Series, London, 1998. - 272 p. DOI: 10.1049/PBEW044E.

16. Bomba A. Mathematical Modeling of Electromagnetic Fields in Irregular Waveguide / A. Bomba, I. Moroz // 2019 IEEE 20th International Conference on Computational Problems of Electrical Engineering (CPEE), 15-18 Sept. 2019. - Lviv-Slavske, 2019. P. 1-4. DOI: 10.1109/CPEE47179.2019. 8949094.

17. Bulavatsky V.M. Fractional Differential Analog of Biparabolic Evolution Equation and Some Its Applications / V. M. Bulavatsky // Cybernetics and Systems Analysis. - 2016. - Vol. 52. - P. 737-747. DOI: $10.1007 / \mathrm{s} 10559-016-9875-5$. 